\title{
Path and site effects deduced from merged transfrontier internet macroseismic data of two recent $M 4$ earthquakes in northwest Europe using a grid cell approach
}

\author{
Koen Van Noten ${ }^{1}$, Thomas Lecocq ${ }^{1}$, Christophe Sira $^{2}$, Klaus-G. Hinzen ${ }^{3}$, and Thierry Camelbeeck ${ }^{1}$ \\ ${ }^{1}$ Royal Observatory of Belgium, Seismology-Gravimetry, Ringlaan 3, 1180 Brussels, Belgium \\ ${ }^{2}$ French Central Seismological Office, University of Strasbourg, Rue René Descartes 5, 67084 Strasbourg CEDEX, France \\ ${ }^{3}$ University of Cologne, Bensberg Erdbebenstation,Vinzenz-Pallotti-Stasse 26, 51429 Bergisch Gladbach, Germany
}

Correspondence to: Koen Van Noten (koen.vannoten@gmail.com)

Received: 3 November 2016 - Discussion started: 9 November 2016

Revised: 15 February 2017 - Accepted: 13 March 2017 - Published: 7 April 2017

\begin{abstract}
The online collection of earthquake reports in $\mathrm{Eu}-$ rope is strongly fragmented across numerous seismological agencies. This paper demonstrates how collecting and merging online institutional macroseismic data strongly improves the density of observations and the quality of intensity shaking maps. Instead of using ZIP code Community Internet Intensity Maps, we geocode individual response addresses for location improvement, assign intensities to grouped answers within $100 \mathrm{~km}^{2}$ grid cells, and generate intensity attenuation relations from the grid cell intensities. Grid cell intensity maps are less subjective and illustrate a more homogeneous intensity distribution than communal ZIP code intensity maps. Using grid cells for ground motion analysis offers an advanced method for exchanging transfrontier equal-area intensity data without sharing any personal information. The applicability of the method is demonstrated on the felt responses of two clearly felt earthquakes: the 8 September $2011 M_{\mathrm{L}} 4.3\left(M_{\mathrm{w}} 3.7\right)$ Goch (Germany) and the 22 May $2015 M_{\mathrm{L}} 4.2\left(M_{\mathrm{w}} 3.7\right)$ Ramsgate (UK) earthquakes. Both events resulted in a non-circular distribution of intensities which is not explained by geometrical amplitude attenuation alone but illustrates an important low-pass filtering due to the sedimentary cover above the Anglo-Brabant Massif and in the Lower Rhine Graben. Our study illustrates the effect of increasing bedrock depth on intensity attenuation and the importance of the WNW-ESE Caledonian structural axis of the Anglo-Brabant Massif for seismic wave propagation. Seismic waves are less attenuated - high $Q$ - along the strike of a tectonic structure but are more strongly atten-
\end{abstract}

uated - low $Q$ - perpendicular to this structure, particularly when they cross rheologically different seismotectonic units separated by crustal-rooted faults.

\section{Introduction}

The online collection of earthquake reports from web-based macroseismic questionnaires is an effective crowdsourcing tool for quasi real-time intensity analysis of the area over which an earthquake was perceived (Atkinson and Wald, 2007; Wald et al., 1999, 2011). Macroseismic intensity assessment describes the ground motion effect over a settled area and contrasts with instrumental intensity, which measures the ground motion at specific sites where seismic instruments are installed (Sbarra et al., 2012a). In poorly instrumented areas, people's earthquake perception provides important seismic information on the earthquake's ground motion. For moderate- to large-magnitude seismic events, the high quantity of responses makes intensity assessment based on web questionnaire data a robust tool (Hough, 2013a; Wald et al., 2011; De Rubeis et al., 2016) not only for tectonic and induced earthquakes but also for non-earthquake-related felt or heard events such as (civil) bomb explosions, sonic booms, construction works and sport/concert events. The concentric pattern of intensity decay is only a theoretical very first approximation, which may serve only to indicate the earthquake's epicentral best location. However, various parameters such as earthquake magnitude, source mechanism, 


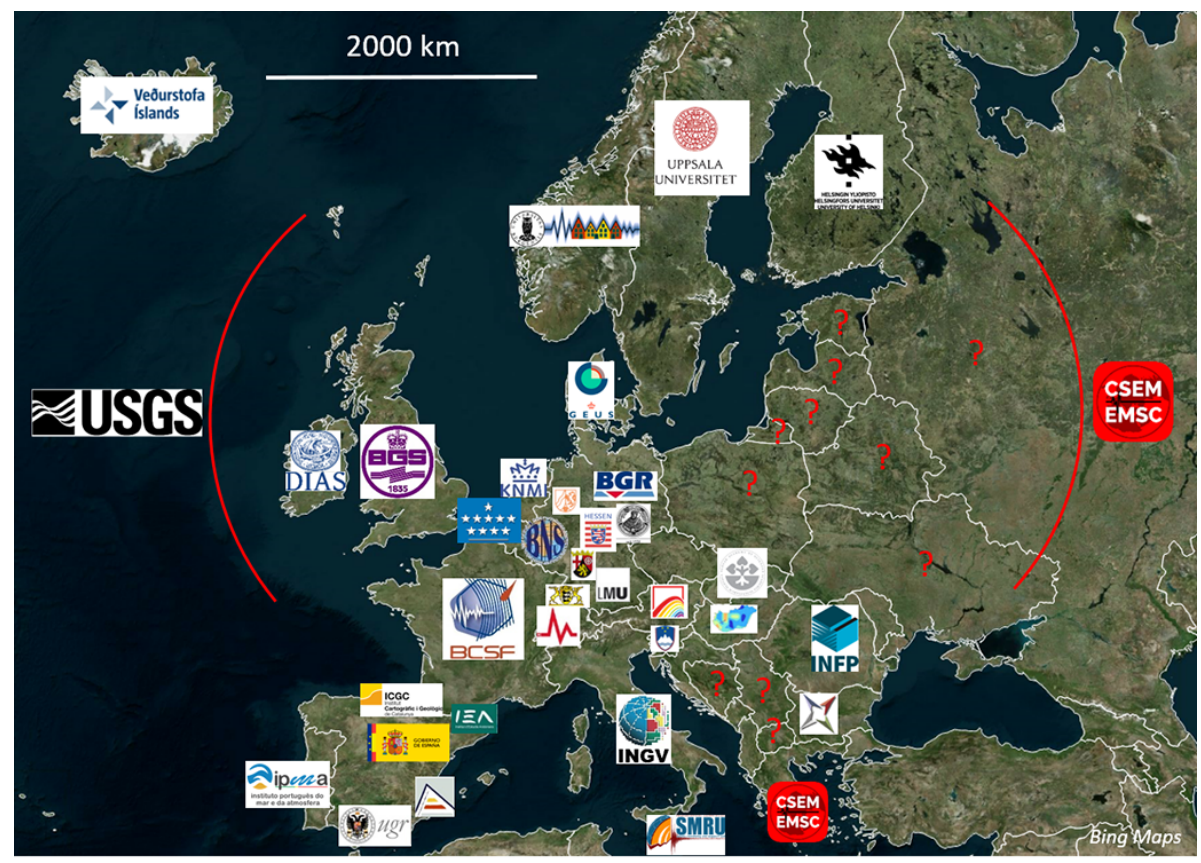

Figure 1. Overview of 33 European and 2 international (EMSC and USGS) seismological agencies that provide an online macroseismic questionnaire to gather witness reports about earthquakes felt throughout Europe. See Appendix A for institutional names and hyperlinks to the online questionnaires. Question marks indicate countries for which an online questionnaire is absent or has not been found online.

site effect and earthquake rupture directivity affect the intensity decay resulting in complex, non-concentric intensity patterns (e.g. Tosi et al., 2000). Macroseismology can reveal these intensity patterns and is therefore often used in conjunction with studies on peak ground acceleration (Atkinson and Wald, 2007; Lesueur et al., 2012; Martin et al., 2015; Souriau, 2006; Worden et al., 2000), site effect analysis (Nguyen et al., 2004; Sbarra et al., 2012a), induced seismicity (Hough, 2014) and vulnerability assessment in civil engineering (García Moreno and Camelbeeck, 2013; Stefano and Chiara, 2014), taking into account population density (Agius et al., 2016; Boatwright and Phillips, 2017).

The "Did You Feel It?" (DYFI?) system of the USGS (please see Appendix A for all institutional abbreviations; other abbreviations are defined in the text) asks questions about nationally and internationally felt earthquakes. The advantage of DYFI? is that macroseismic data are collected systematically over the whole North American continent and worldwide through a well-calibrated algorithm (Dengler and Dewey, 1998; Worden et al., 2000). In Europe, however, the situation is more complex: at least 33 seismological institutes in 23 countries and 2 international institutes (EMSC and USGS) manage and maintain their own web-based macroseismic questionnaire (Fig. 1; see Appendix A for hyperlinks). Despite this high number of inquiries, only a minority of these national institutes, i.e. BGS, INGV, BCSF, SED, IGN, ROB-BNS, calculate and map intensities from people's submissions online and update a macroseismic map in quasi real time (a small amount of time is still needed to process the data). The ROB shares its questionnaire with the BNS of the University of Cologne (Germany) to collect transfrontier macroseismic information across the BelgianGerman border (ROB-BNS network; Lecocq et al., 2009). In the ROB-BNS questionnaire, responses are automatically forwarded to BCSF if an earthquake is located in France, and consequently macroseismic data are shared in real time between these institutes. Another transfrontier collaboration is SISPyr (www.sispyr.eu), in which macroseismic data from IGN and BCSF are shared to create a unique ShakeMap of the Pyrenees. Germany has no organized national inquiry, which results in eight different institutes gathering macroseismic data (Appendix A). Other national inquiries are often known to the local population, but unfortunately the macroseismic maps are not always shown online.

The benefit of having different European inquiries is that every institute has made the inquiry available in its own national language(s) and hence can deal with specifics in their language in the open comment box. However, disadvantages are that (1) people can answer multiple national or international inquiries when they felt an earthquake and (2) the data on the perception of transfrontier-felt seismic events is strongly fragmented across different institutes and countries. Merging databases carries the risk of duplicate entries in the database but, more importantly, also has the risk of merging intensities that result from different questionnaires, countries and intensity calculation algorithms, which will smooth 
the mean of the merged intensities. Because of this European fragmentation and intensity variability, performing a proper macroseismic assessment of transfrontier-felt earthquakes remains a complex and not straightforward task. Contemporary transfrontier macroseismic maps are either based on historical reports (e.g. Camelbeeck et al., 2014; Cara et al., 2005; Knuts et al., 2015; Kronrod et al., 2013) or on communal reports, such as those used to map the $1992 M_{\mathrm{L}}$ $5.8\left(M_{\mathrm{w}} 5.3\right)$ Roermond earthquake (NL; Haak et al., 1994) and the $2003 M_{\mathrm{L}} 5.4\left(M_{\mathrm{W}}\right.$ 4.9) Rambervillers (FR) earthquake (Cara et al., 2005). These successful efforts in (historical) macroseismology indicate that a comprehensive method is needed to merge the scattered online macroseismic data; however, in northwest Europe, such a methodology is currently not implemented. Examples of transfrontier macroseismic maps developed from classical inquiries (communal reports and field surveys), e.g. the $2003 M_{\mathrm{L}} 5.4\left(M_{\mathrm{W}} 4.9\right)$ Rambervillers (FR) and 2004 Waldkirch (DE) earthquakes, all show a good equivalence in intensities at the borders, which justifies merging databases.

In a web-based inquiry, it is essential and obligatory for the respondent to provide the postcode from the community where the earthquake was felt (Wald et al., 1999). This allows constructing ZIP code Community Internet Intensity Maps (ZIP-CIIMs) from which the geometric spreading of the macroseismic intensity can be evaluated. For earthquakes with a sufficiently large magnitude to be felt in numerous communities, the ZIP-CIIM usually provides a good overview of the affected area (e.g. Horton et al., 2015; Hough, 2012) and gives valuable information on the intensity decay with increasing epicentral distance. In many European countries, ZIP code areas are small in densely populated areas and large in remote areas. A ZIP-CIIM has thus the advantage that the number of potential respondents per ZIP code can roughly be the same. The big downside of using ZIP-CIIMs, however, is the irregularity of the municipality shapes resulting in an inhomogeneous spatial coverage of intensities over the area in which the earthquake was felt.

Another common flaw of online macroseismic data is that epicentral intensities are often underestimated (Sira et al., 2016). Intensities at a large epicentral distance, on the other hand, are often overestimated because people who have not felt the earthquake usually do not rush to the internet to find information and share their experience. This usually results in a lack of intensity I (not-felt) reports. These not-felt responses are important as they prevent the average intensity in a community being too high at a large epicentral distance. The underrepresentation of low intensities is not just an effect of population size within a ZIP code area because the number of responses in a community usually scales with the population size (Boatwright and Phillips, 2017; Mak and Schorlemmer, 2016). Currently, INGV deals with this problem by reaching out to volunteers after an earthquake occurred near their location to request their (not-)felt experience. This allows a distinction between intensities I, II and
III and the avoidance of intensity overestimation (Sbarra et al., 2010). Boatwright and Phillips (2017) apply a weighted intensity normalization based on the response reaction to include underreporting and non-reporting ZIP codes in the attenuation analysis. Unfortunately their normalization factor is currently only applicable to Californian earthquakes.

In this study, intensities are processed by grid cell mapping, which ensures a more homogeneous spread of intensities than in a ZIP-CIIM. In our procedure, the address of individual intensity data points (IDPs) is first geocoded into their geographical coordinates, and, second, an intensity is assigned to equally sized grid cells covering the affected area. Cell size is chosen to be large enough $\left(100 \mathrm{~km}^{2}\right)$ to capture enough responses. This method allows merging IDPs which are collected by different institutes and of which the respondents' location may be imprecise. The applicability of the method is demonstrated on two particularly clearly felt, moderate-magnitude earthquakes that struck northwestern Europe, but which did not result in any reported damage: the 8 September $2011 M_{\mathrm{L}} 4.3\left(M_{\mathrm{S}} 4.1, M_{\mathrm{w}} 3.7\right)$ Goch earthquake (DE) and the 22 May $2015 M_{\mathrm{L}} 4.2\left(M_{\mathrm{W}} 3.7\right)$ Ramsgate earthquake (UK). Both earthquakes caused noncircular distributions of intensities across northwestern Europe and their perception in Belgium, Germany, the Netherlands, Luxemburg, France and the UK definitely classifies them as "transfrontier". For each earthquake, (inter)national institutional online macroseismic responses were collected and merged. This study provides a post-seismic (not yet applied in real time) methodology of how European macroseismic datasets can be successfully merged and demonstrates why the studied events had non-circular intensity distributions, taking into account source mechanism, population density, geology, bedrock depth and intensity distributions of past earthquakes.

\section{Methodology}

\subsection{Geocoding}

Because intensity is determined for each ZIP code, ZIPCIIMs cover irregular shapes on maps causing the intensity locations to be imprecise. In a macroseismic questionnaire, people are asked to provide their ZIP code to generate to ZIPCIIM, but they are also free to provide their street address. Analysing the address columns in the ROB-BNS (31929 individual reports since 2002$)$ and BCSF ( $~ 80000$ individual reports since 2000) macroseismic databases shows that $\sim 89$ and $\sim 76 \%$ of people, respectively, freely give their personal address. Given these high percentages, in this study the respondent's location (address) is first geocoded to its true geographical coordinates to improve the spatial resolution of the macroseismic data and to provide a more realistic spread than in ZIP-CIIMs. Although many official geocode systems such as postal services, official cadastre plans and governmen- 


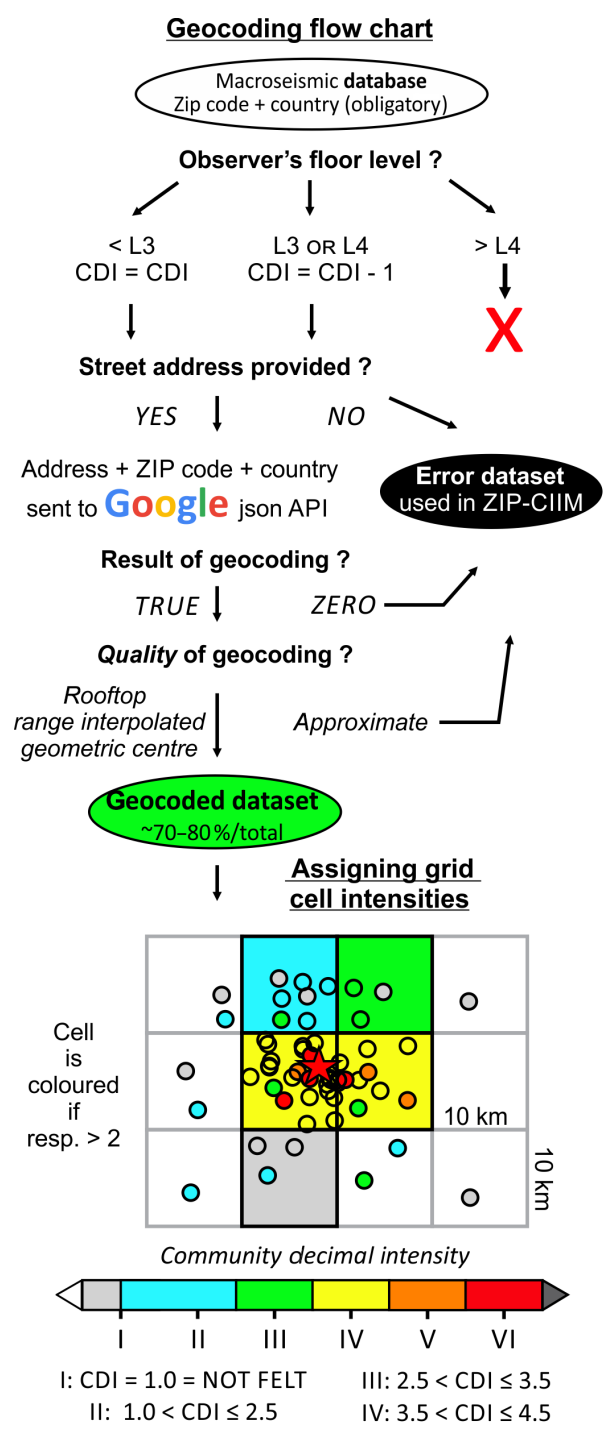

Figure 2. Geocoding flow chart and grid cell intensity procedure. Input addresses are send to a Google ${ }^{\text {TM }}$ JSON API in which addresses are corrected and geocoded. Precision of the geocoded coordinates is quantified by a quality factor. For absent, unrecognized or imprecise (too low-quality) addresses, the geocoded response is not used for grid cell intensity assessment. All geocoded addresses are grouped within $100 \mathrm{~km}^{2}$ grid cells. Cells with at least three responses are coloured to the mean intensity.

tal services provide very accurate locations, these geocoding services usually require an exact and correct address input of the respondent and often cannot deal with abbreviations and typographical mistakes. Exploring the address list in the macroseismic ROB-BNS and KNMI databases shows that people frequently abbreviate their street address to their convenience (e.g. "av.", "av", "ave" for "avenue", "str", "st" for "street"; "o", "nr", "No." for house number) and regularly make accidental typographical mistakes.
To account for these inconveniences, a straightforward algorithm (Fig. 2) was developed to send addresses automatically to a Google ${ }^{\mathrm{TM}}$ JSON API to geocode the data. The free edition of the Google JSON API is currently limited to 2500 address conversions per day which currently limits using Google for real-time geocoding of a large number of responses to large-magnitude earthquakes (unless a business account is bought). We prefer the use of Google above the official services because it corrects addresses with typographical errors and the precision of the geocoded location is weighted by the following four quality factors:

1. rooftop quality: precise location to the street address;

2. range-interpolated and geometric centre quality: location is as good as the street location;

3. approximate quality: address could not be located; either the ZIP code centre or a community location near the address is returned after geocoding.

As the approximate quality is too uncertain to be used, any address that has this quality was rejected from geocoded databases in this study (Fig. 2). Depending on the user's needs, different quality factors and thus different subsets of the database can be selected for macroseismic intensity assessment. For a detailed intensity evaluation of a local site, for instance, only the roof top quality could be used to ensure a correct location. After geocoding, we automatically calculate the epicentral distance from the precise location of the observer to the epicentre obtained by instrumental data, which facilitates the evaluation of intensity distance attenuation.

The ROB-BNS geocoding system was first applied on 301 inquiries ( 235 geocoded) submitted by people that reacted to an air blast caused by the accidental explosion of a WWII bomb on 3 January 2014 at Euskirchen (Germany; Hinzen, 2014). Although a geocoded map uses fewer responses and presents a subset of the data, the distribution of IDPs significantly improved the interpretation of the macroseismic field compared to a ZIP-CIIM.

\subsection{Intensity adjustment}

Earthquake vibrations are more strongly observed at higher floors due to wobbling of the building. This results in a higher macroseismic intensity of responses from higher floors (Sbarra et al., 2012b). We follow the European Macroseismic Scale 98 (EMS-98) recommended guideline (Grünthal et al., 1998) to not take into account responses from people in basements or living at floor level five and above. However, no clear guideline is prescribed in EMS-98 to reduce the assigned intensity of responses coming from floors one to four. We apply a floor-level intensity correction of one intensity decrease for all responses from people living at floor levels three and four in a multistorey building but with a minimum value of intensity II to indicate that the earthquake was 
still felt. Entries from people living on the ground floor and floor levels one and two were not rescaled.

\subsection{Grid cell intensity analysis}

The distance decay of a geocoded dataset has a larger scatter than the distance decay of averaged intensities from a ZIP code dataset (Haase and Park, 2006) because individual intensities at large distances are not ruled out. To account for this statistical problem, Wald et al. (1999) subdivided ZIP codes by regularly sized grids of a few kilometres, i.e. smaller than an average community polygon, for which more realistic intensities can be calculated. In this work, a similar grid cell approach is followed: after geocoding all IDPs, we first structure the model area where the earthquake was perceived by dividing it into $100 \mathrm{~km}^{2}(10 \mathrm{~km}$ by $10 \mathrm{~km})$ grid cells and, second, assign an average intensity to the cells. This cell size can be considered as equivalent to a macroseismic data point (MDP), which is used in historical seismology to group IDPs and which on average has the size of a small city, according to the AHEAD (Archive of Historical Earthquake Data) guidelines (Rovida and Locati, 2015).

Intensity degree definitions recommend the evaluation of the percentage of people observing an earthquake effect, of which each effect is associated with an intensity value. Grouping the intensity values of a large number of responses in ZIP code areas leads to a robust intensity assessment. Unfortunately, the European macroseismic fragmentation complicates applying this procedure. The transfrontier Goch and Ramsgate macroseismic data that were provided to us by the (inter)national agencies only contained "individual" intensities and not the detailed answers to the questions. Hence, the recommended procedure could not be followed. Moreover, in numerous cases, the number of individual data collected in cells is often insufficient to realize a representative statistical processing of the intensity. For these reasons we calculate the mean intensity of all (geocoded if possible) individual intensities within a cell. This grid cell intensity is an approximation of the intensity field and provides no certified EMS-98 value, but it provides a solution to obtain a rapid severity of shaking after merging data. To avoid the influence of one data point on the mean intensity, an intensity value is only assigned to those cells that have a least three responses (Fig. 2). The grid cell calculation is performed in QGIS (QGIS, 2016). In what follows, grid cell intensity values are either noted in decimals (e.g. a CDI of 3.7) or in Roman numbers in which intensities are rounded between x.5 and $1+$ x.5 (e.g. a CDI of 3.7 results in intensity IV). Cells with a mean CDI of $1>\mathrm{CDI}<2.5$ are coloured as intensity II indicating that the earthquake was felt in that cell (Fig. 2).

\section{Seismotectonic framework}

\subsection{The 2011 Goch earthquake in the Lower Rhine Graben (LRG)}

The Goch earthquake occurred on Thursday, 8 September 2011, at 19:02:50 UTC (21:02:50 local time) close to the German-Dutch border near the town of Goch (population of $34000, \mathrm{DE}$ ). The nearest bigger city is Nijmegen (population $160000, \mathrm{NL}), 25 \mathrm{~km} \mathrm{NW}$ of the epicentre. Waveform analysis of seismograms recorded by different seismic stations within the ROB-BNS network resulted in an epicentre location of $51.668^{\circ} \mathrm{N} \pm 2.7 \mathrm{~km}, 6.162^{\circ} \mathrm{E} \pm 2.4 \mathrm{~km}$ (Fig. 3) and a depth estimation of $10 \mathrm{~km} \pm 1.2 \mathrm{~km}$. The depth uncertainty is due to poor epicentral station coverage. The instrumental magnitude was determined to be $M_{\mathrm{L}} 4.3 \pm 0.3$ and $M_{\mathrm{W}}$ $3.7 \pm 0.3$. The Goch earthquake occurred at the northeast lateral end of the LRG, i.e. the most seismically active tectonic graben structure in northwest Europe. The LRG is defined by NW-SE-oriented normal faults that are the cause of moderate seismicity (Vanneste et al., 2013). The dominant seismic activity within the LRG is clustered in the southern and southwestern part (Fig. 3). The LRG forms an asymmetric horst and graben structure of which the main graben is the Roer Valley graben. Its eastern boundary is defined by the Peelrand boundary fault, along which the $M_{\mathrm{L}} 5.8\left(M_{\mathrm{w}} 5.4\right) 1992$ Roermond earthquake occurred (Camelbeeck and van Eck, 1994). The Venlo Graben (VG in Fig. 3) is a smaller half-graben situated northeast of the Roer Valley graben and is bordered in the northeast by the Viersen Fault (VF in Fig. 3), a Quaternary, active, $\sim 53 \mathrm{~km}$ long continuous fault running from the German-Dutch border in the northwest to Mönchengladbach in the southeast.

The focal mechanism of the Goch earthquake from the $P$ wave polarities of stations within the ROB-BNS network shows a left-lateral strike-slip faulting mechanism (Fig. 3; strike: 354.3; dip: 76; rake: 1.7). Based on a mean fault strike orientation of $332^{\circ}$ (Vanneste et al., 2013) for the Viersen Fault, the $354^{\circ}$ nodal plane corresponds with the true fault plane and the E-W nodal plane as the auxiliary plane. The link between seismicity and the faults mapped at the surface or inferred faults at depth in the LRG is in many cases not obvious due to imprecise depth location or due to the stepping character of some faults (Hinzen and Reamer, 2007). The Goch epicentre is located $6 \mathrm{~km} \pm 2.7 \mathrm{~km} \mathrm{NE}$ of the surface trajectory of the SW-dipping Viersen Fault. Given the $10 \mathrm{~km}$ source depth, it is thus not possible to attribute the Goch earthquake to the Viersen Fault. A more likely source is a fault strand parallel to the Viersen Fault, such as mapped in Ahorner (1962). The left-lateral strike-slip mechanism is consistent with a maximum horizontal compressional stress oriented $310^{\circ}$, an orientation within the range of the NWSE-oriented regional stress tensor variation within the LRG (Camelbeeck and van Eck, 1994; Hinzen, 2003). The Goch earthquake is remarkable because it occurred without any 


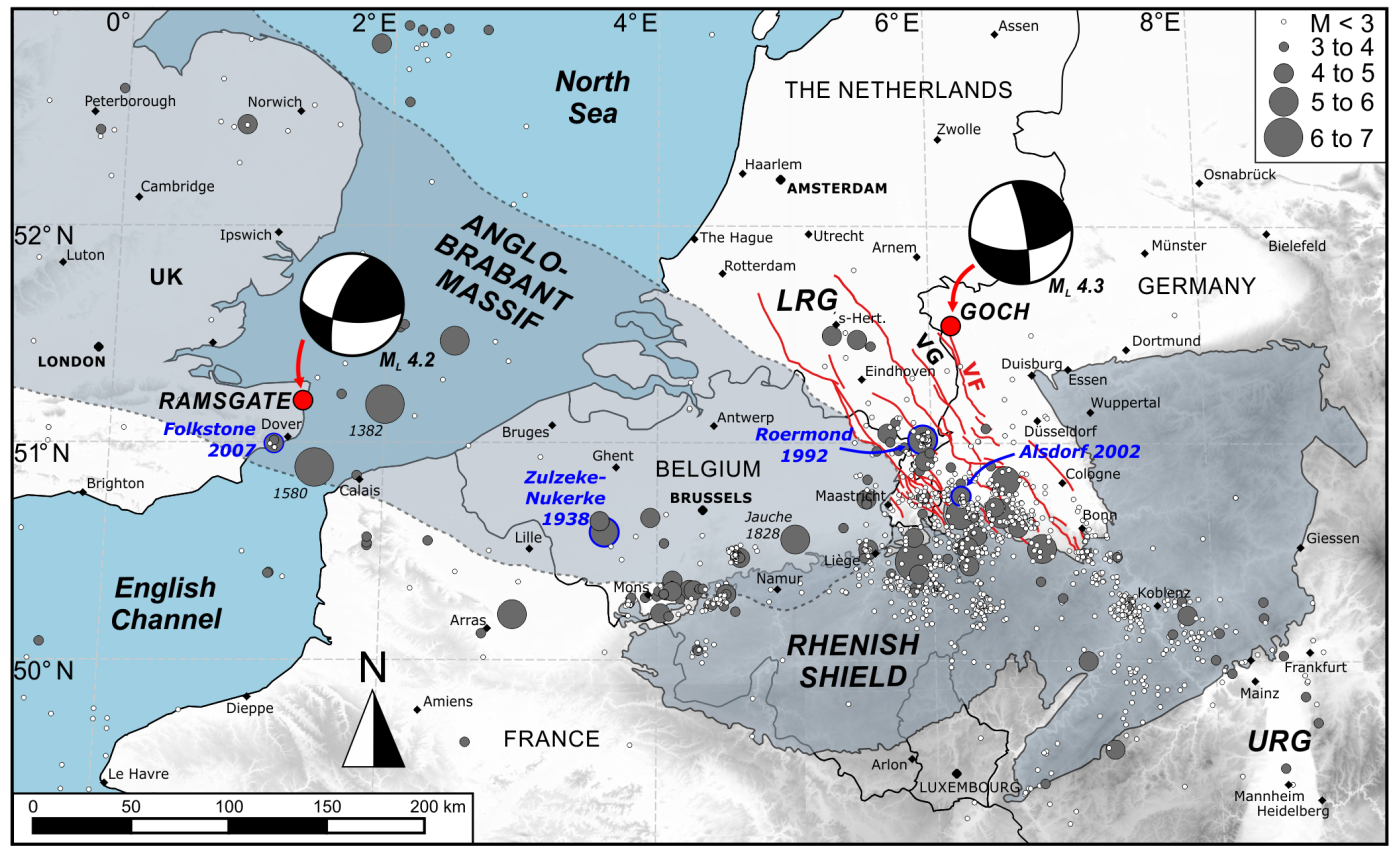

Figure 3. Combined ROB-BNS and BGS instrumental and historical seismic catalogues illustrated on the $30 \mathrm{~m}$ SRTM-DEM (Shuttle Radar Topography Mission digital elevation model). The $2011 M_{\mathrm{L}} 4.3$ Goch earthquake (red dot) occurred at the northeast end of the Venlo Graben (VG), close to the Viersen Fault (VF) in the northeast part of the Lower Rhine Graben (LRG). The $2015 M_{\mathrm{L}} 4.2$ Ramsgate earthquake (red dot) took place offshore of the UK within the basement rocks of the Anglo-Brabant Massif, which extends from northern Belgium to the southeast UK. URG: Upper Rhine Graben. Macroseismic surveys of earthquakes indicated in blue are discussed in the text.

measured aftershocks and because of its isolated position in the northeast part of the LRG and Venlo Graben; after all, the instrumental catalogue of the ROB (since 1985) lists no earthquake within a radius of $20 \mathrm{~km}$ around the Goch epicentre.

\subsection{The 2015 Ramsgate earthquake in the Anglo-Brabant Massif (A-BM)}

The Ramsgate earthquake occurred on Friday, 22 May 2015, at 01:52:17 UTC (02:52:17 local time) with an epicentre $3 \mathrm{~km}$ offshore of the eastern coast of the United Kingdom in the Strait of Dover. The closest town is Ramsgate, a small coastal town (population 40000 ) in the county of Kent, southeast of London. The Ramsgate earthquake was located at $51.304^{\circ} \mathrm{N}, 1.438^{\circ} \mathrm{E}$ according to the BGS (Fig. 3) and estimated at a depth of $15 \mathrm{~km}$. This location corresponds well to the $51.283^{\circ} \mathrm{N}, 1.409^{\circ} \mathrm{E}$ location derived from the ROBBNS network. The instrumental magnitude was determined to be $M_{\mathrm{L}} 4.2$ according to the BGS. The focal mechanism is an oblique thrusting mechanism along a NE-SW thrust fault (Fig. 3) with a ruptured area of a small extent $\left(\sim 1 \mathrm{~km}^{2}\right)$.

Small to moderate-sized earthquakes are not unusual for the low-to-moderately active seismic zone of the Strait of Dover and Pas de Calais (Musson, 2004). The latest event felt in this region was the 28 April $2007 M_{\mathrm{L}} 4.3\left(M_{\mathrm{w}} 3.9\right)$ Folkestone earthquake located $27 \mathrm{~km} \mathrm{SW}$ of Ramsgate, causing small damage in the Foord district at Folkestone (Ottemöller et al., 2009; Ottemöller and Sargeant, 2010; Sargeant et al., 2008). Other larger magnitude events that caused strong ground motions and damage in the UK, France and Belgium are the historical earthquakes of 21 May $1382\left(M_{\mathrm{S}} 6.0\right)$, 23 April $1449\left(M_{\mathrm{S}} 5.5\right)$ and 6 April $1580(M \sim 6)$, rather poorly located by macroseismic analysis (Melville et al., 1996) but felt at an epicentral distance of up to $\sim 400 \mathrm{~km}$ on the continent (Camelbeeck et al., 2007). Given their depths, the sources of the Folkestone, Ramsgate and the moderatemagnitude North Sea earthquakes are expected to be along Caledonian faults in the basement rocks of the A-BM: the Lower Palaeozoic massif north of the Variscan Front, which extends from a WNW-ESE orientation in the southeastern part of the UK to central and north Belgium to a ENE-WSW orientation in eastern Belgium (Fig. 3). Seismicity within the seismotectonic zone of the A-BM is considered to be low to moderate (Camelbeeck et al., 2007); however, the largest onshore earthquake ever recorded on Belgian territory, i.e. the Zulzeke-Nukerke 11 June $1938 M_{\mathrm{s}} 5.0$ earthquake (Fig. 3), occurred within the A-BM, indicating that large-magnitude earthquakes can occur. 
Table 1. Institutional macroseismic data for the 2011 Goch earthquake. When street addresses were available, response locations were geocoded for location improvement. Intensities were floor-level corrected. Only total amount of geocoded and corrected intensity points are used for grid cell intensity analysis in this study. $M_{\mathrm{L}}$ : local magnitude; $M_{\mathrm{W}}$ : moment magnitude; no. of inq: number of inquiries; I max: maximum intensity.

\begin{tabular}{llrrrrrrrr}
\hline Event & Agency & $M_{\mathrm{L}}$ & $M_{\mathrm{W}}$ & No. of inq & $\begin{array}{r}\text { Geocoded \& } \\
\text { corrected }\end{array}$ & $\begin{array}{r}\text { Not felt } \\
\text { reports }\end{array}$ & $\begin{array}{r}\% \text { Not } \\
\text { felt }\end{array}$ & depth & I max \\
\hline Goch & ROB-BNS & 4.3 & 3.7 & 3294 & 2134 & 284 & $13 \%$ & 10 & VI \\
Thursday & KNMI & 4.5 & - & 4222 & 3637 & 272 & $7 \%$ & 10.3 & VI \\
08/09/2011 & NRW-GD & 4.3 & - & 1199 & 1149 & 0 & $0 \%$ & 11 & V \\
19:02:50 UTC & National agencies subtotal: & $\mathbf{8 7 1 5}$ & $\mathbf{6 9 2 0}$ & $\mathbf{5 5 6}$ & $\mathbf{8} \%$ & & \\
& EMSC & 4.3 & - & 533 & 533 & 13 & $2 \%$ & 10 & V \\
& USGS & - & - & 1038 & 1038 & 94 & $9 \%$ & - & VI \\
\hline
\end{tabular}

Table 2. Institutional macroseismic datasets for the 2015 Ramsgate earthquake. When street addresses were available, response locations were geocoded for location improvement. Intensities were floor-level corrected. Only total amount of geocoded and corrected intensity points are used for grid cell intensity analysis in this study. ML: local magnitude; MW: moment magnitude; no. of inq.: number of inquiries; I max: maximum intensity. No. of inq. gathered by BGS (in italics) are taken from the BGS website but were not used in the individual intensity analysis.

\begin{tabular}{|c|c|c|c|c|c|c|c|c|}
\hline Event & Agency & $M_{\mathrm{W}}$ & No. of inq & $\begin{array}{r}\text { Geocoded \& } \\
\text { corrected }\end{array}$ & $\begin{array}{r}\text { Not felt } \\
\text { reports }\end{array}$ & $\begin{array}{r}\% \text { Not } \\
\text { felt }\end{array}$ & depth & $\mathrm{I} \max$ \\
\hline Ramsgate & BGS & 4.2 & 1860 & - & - & - & 12 & V (epi) \\
\hline Friday & BCSF & 4.0 & 250 & 216 & 37 & $17 \%$ & 10 & IV \\
\hline $22 / 05 / 2011$ & ROB-BNS & 4.1 & 1993 & 1618 & 166 & $10 \%$ & 15 & III \\
\hline \multirow{4}{*}{ 01:52:17 UTC } & \multicolumn{2}{|c|}{ National agencies subtotal: } & 4103 & 1834 & 203 & $11 \%$ & & \\
\hline & EMSC & 4.2 & 1963 & 1963 & 53 & $3 \%$ & 10 & V (epi) \\
\hline & USGS & 3.7 & 156 & 156 & 4 & $3 \%$ & 10 & IV \\
\hline & \multicolumn{2}{|c|}{ Total responses: } & 6222 & 3953 & 260 & $7 \%$ & & \\
\hline
\end{tabular}

\section{Results: transfrontier macroseismic grid cell intensity analysis}

\subsection{Integrating macroseismic databases}

The 2011 Goch event was widely felt in Germany, Belgium, Luxemburg and the Netherlands. Macroseismic data were collected by the ROB-BNS network, the KNMI in the Netherlands and the NRW-GD in Germany, a network that overlaps with the ROB-BNS network. Felt reports for the 2015 Ramsgate event were collected by the ROB-BNS network for Belgian territory, the BCSF for the French territory and the BGS in the UK. The EMSC and USGS also assembled transfrontier felt witness reports of the two earthquakes (Tables 1 and 2).

To fully understand the effect of seismic radiation across the national borders of countries where the Goch and Ramsgate earthquakes were perceived, it was crucial to collect and merge all available macroseismic data from these (inter)national agencies. As the national agencies also collect international macroseismic data, overlap exists in the macroseismic dataset (Fig. 4). Macroseismic data were freely avail- able upon request from all institutes, after the personal information was removed. To protect the location of the respondent, the USGS provided a list in which the geographical location coordinates were truncated at two decimal digits. The precision of the response is therefore limited within a range of $1.11 \mathrm{~km}$, causing some responses to overlap on the map. The NRW-GD also protected the location data up to three decimal digits with a location error of $0.11 \mathrm{~km}$ (Fig. 2). Although truncation limits the response precision, it does not pose a problem for intensity analysis as all available macroseismic data are grouped within $100 \mathrm{~km}^{2}$ cells, which are much larger than the individual location error. Geocoding of ROB-BNS, KNMI and BCSF responses provided precise locations due to the Google quality factor. Merging different macroseismic data sources allows having more data and provides a denser spatial coverage of the area over which the earthquake was felt. It, however, also increases the variability of the dataset due to increased uncertainty in the respondents' locations as different location procedures are used by the agencies. 


\subsection{Comparing institutional questionnaires}

The collection of macroseismic data by means of a questionnaire has been carried out in different European countries for a long time. In Table S1 in the Supplement all questions present in the different institutional questionnaires of the seven institutes from which data are used in this study are compared. Questions concern the typical effects on a person's situation when the earthquake occurred, the perception and experience of the earthquake, and earthquake effects on furniture, buildings and the environment. Each questionnaire has either been developed from an older form for a local intensity scale or is modified according to the pioneering online questionnaire of Wald et al. (1999). Most questions are rather similar but each questionnaire does have its specifics and no two institutional questionnaires are completely alike. The impact of having different questions in a questionnaire on the intensity scale is unknown and will be investigated in this study. Hough et al. (2016) reported substantial differences between the macroseismic datasets of the Nepal Ghorka earthquake.

\subsection{The $M_{\mathrm{L}} 4.3$ Goch earthquake}

\subsubsection{ROB-BNS}

The questionnaire used by the ROB-BNS network (see Lecocq et al., 2009) is largely based on the standardized questionnaire of Wald et al. (1999) using standard statistical procedures and rejections following Dengler and Dewey (2000). Based on the answers, a decimal community intensity (CDI) value is determined following the computer algorithm of Wald et al. (1999). In the ROB-BNS database, duplications (same name, address, personal details) were manually deleted. High intensities, i.e. more than three intensity units above the intensity attenuation relation (IAR; see below), at large epicentral distances were deleted. The ROB-BNS database (3294 responses) shows the largest geographical spread, mainly because the questionnaire is provided in four languages (see Appendices A and B) allowing a survey far across the national borders. A total of 2307 addresses $(69 \%)$ of the ROB-BNS database could be geocoded. This rather low percentage is mainly because a large amount of German responses lacked street address information. After floor-level correction 2134 responses $(65 \%)$ remained for grid cell intensity analysis (Table 1). Floor-level correction affects the grid cell intensities of large cities: Brussels and Verviers in Belgium, and Cologne, Düsseldorf, Wuppertal and Essen in Germany as they all rescaled from intensity III to intensity II. Intensity IV occurs in all cells in an area of $30 \mathrm{~km}$ around the epicentre. Maximum CDIs are 4.4 and 4.1 in the cells $15 \mathrm{~km}$ south and $15 \mathrm{~km}$ north of the epicentre, respectively. Epicentral CDI is 3.7. The ROB-BNS macroseismic distribution is underrepresented northwest of the epicentre in the Netherlands at a larger epicentral distance (Fig. 4).
Only for the ROB-BNS responses could the timing of submissions be evaluated. Submissions are spread between a few minutes and 3 days after the event. Overall, 50 and $75 \%$ of the data were submitted within the first 3 and $14 \mathrm{~h}$, respectively; $95 \%$ of data was reached after the evening news flash of 9 September 2009 (Fig. S1, Supplement).

\subsubsection{KNMI}

The KNMI questionnaire resulted in 4222 responses; 3638 (86\%) locations were geocoded to street level or better. As the KNMI enquiry is only provided in Dutch, almost all responses (except from five entries at Emmerich am Rhein in Germany) were submitted from in the Netherlands (Fig. 4). After floor-level correction, 3637 responses remained for intensity analysis. Floor-level intensity correction did not lead to an intensity decrease in any grid cell, not even in major cities such as Nijmegen, Utrecht, Rotterdam or Amsterdam. Intensity IV is assigned to three cells to the west and northwest of the epicentre, located south of Nijmegen (NL; Fig. 4). An epicentral intensity cannot reliably be calculated due to a lack of data points (only three available) in the epicentral grid cell.

\subsubsection{NRW-GD}

A proper intensity could be assigned to 1149 entries of the NRW-GD questionnaire. As the questionnaire is only provided in German, almost all responses, expect one from Heijen (NL), were submitted from within Germany. NRW-GD provided truncated, three-digit individual coordinates. The intensity procedure is unknown but the questionnaire results in half-intensity units. Intensity data cannot be floor-level corrected as the floor-level question is absent (Q8, Table S1). Remarkably, the NRW-GD questionnaire also lacks the question of whether the earthquake was felt or not (Q13, Table S1). This results in an absence of not-felt reports (Table 1) and hence intensity I in the distribution (Fig. 5). The halfintensity units and absent floor-level and not-felt questions strongly affects the intensity distribution in the grid cells (Fig. 5) with respect to the other institutes. In the affected German area, NRW-GD grid cell intensities are systematically higher (on average a half unit but sometimes more than one unit) than the grid cell intensity of ROB-BNS. Grid cell intensity in Düsseldorf, for example, was rescaled after floor-level correction to CDI 2.5 in the ROB-BNS database, whereas in the NRW-GD the intensity is CDI 3.3. There are also many isolated grid cells, sometimes $100 \mathrm{~km}$ from the epicentre (e.g. Wuppertal, Dortmund; Fig. 4), that still show intensity IV although in the ROB-BNS database intensity III is assigned to these cells or they are even floor-level corrected to intensity II. 


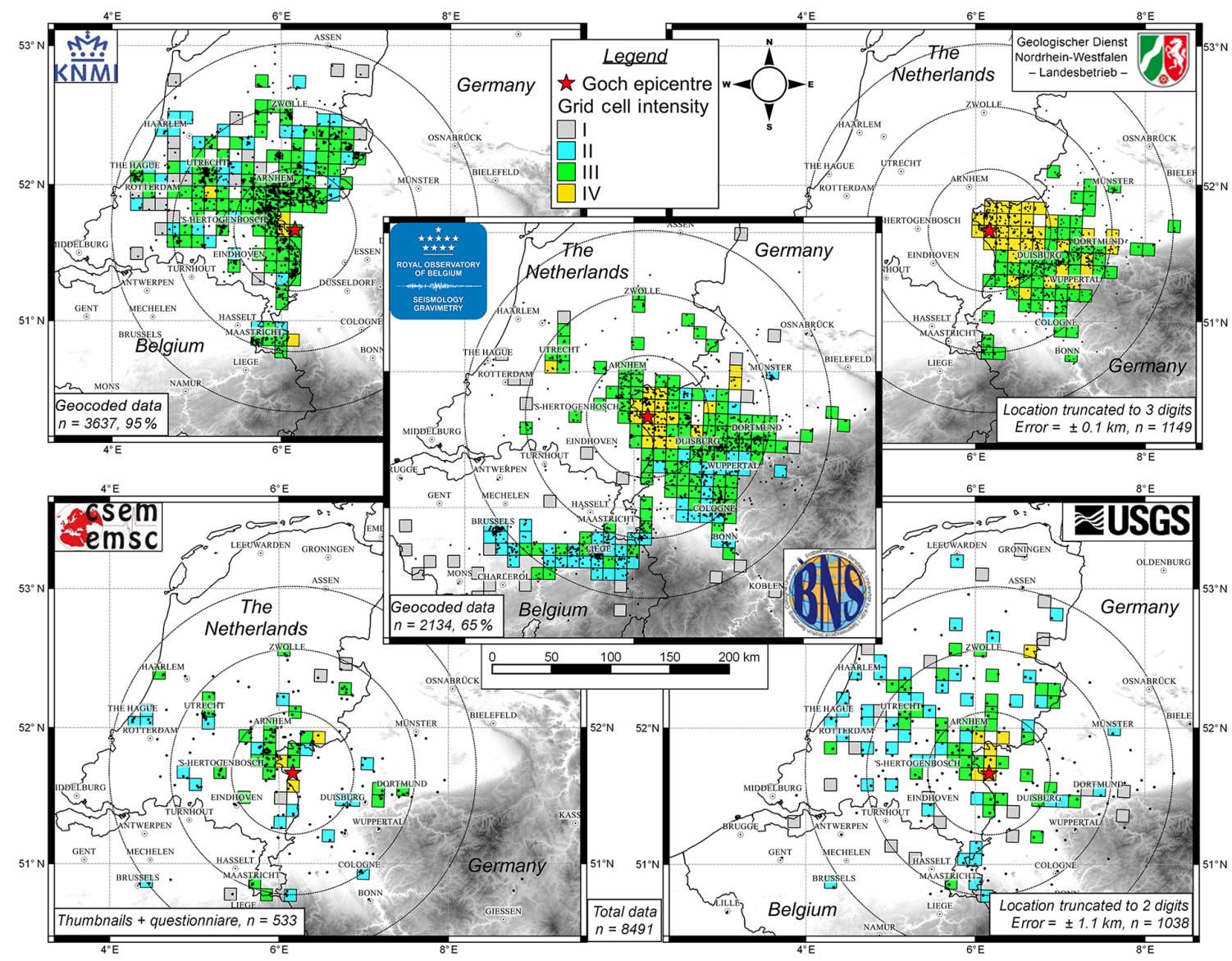

Figure 4. Fragmentation of macroseismic data of the 2011 Goch earthquake. Transfrontier collaborations (ROB-BNS) and international institutes (USGS, EMSC) that provide an English or a multilanguage inquiry cover a wider geographical spread than national inquiries (KNMI, NRW-GD). ROB-BNS and KNMI datasets are geocoded (percentage indicates the amount of data used in the grid cell analysis). Grid cell size is $100 \mathrm{~km}^{2}$. Only cells with at least three entries are coloured. Circles represent 50, 100 and $150 \mathrm{~km}$ epicentral distance.

\subsubsection{EMSC}

At the EMSC, macroseismic data are collected in two different ways: (1) through a classic questionnaire; (2) via a list of thumbnails (cartoons) describing shaking level (Bossu et al., 2008). Thumbnail intensities provide full-intensity integers, whereas intensity data from the questionnaire result in a CDI with one digit. The information gathered from the questionnaires is divided into an optimal number of clusters, and a representative intensity is assigned to each cluster (Amorèse et al., 2015). At least five responses are needed in order to assign an EMS-98 intensity to a cluster. The cluster data are comparable to a grid cell, although clusters may have different sizes. The floor-level question (Q8, Table S1) is present in the EMSC web form but is not taken into account in the intensity estimation.

Overall, 259 people reported to the EMSC via the thumbnails and 274 via the questionnaires. Plotting individual thumbnail locations on a satellite map shows that the locations are often not geocoded for rooftop quality. Most re- sponses came from the Netherlands and Germany. Because of the low amount of data, dividing the affected area into grid cells results in a fragmented image of the affected area (Fig. 4). In the epicentral area, intensity IV is never reached in the results of the thumbnails. This contrasts with the clustered data of the EMSC obtained via the questionnaire, in which intensity $\mathrm{V}$ was assigned to the clusters of the epicentral area.

\subsubsection{USGS}

After collecting individual responses, the USGS assigns a weighted value to the answers of different questions (i.e. the felt index, shelf index and damage index). The responses are then averaged to reflect a consensus of the grouped answers. DYFI? employs the modified Mercalli intensity scale (MMI). Intensities assigned by the MMI and EMS-98 and other modern scales are found to correspond closely to each other (Hough, 2013a) and can thus be merged. We use weighted, one-digit CDI intensities from 1038 people who reported to the USGS to have felt the Goch earthquake. Floor-level in- 
(a)

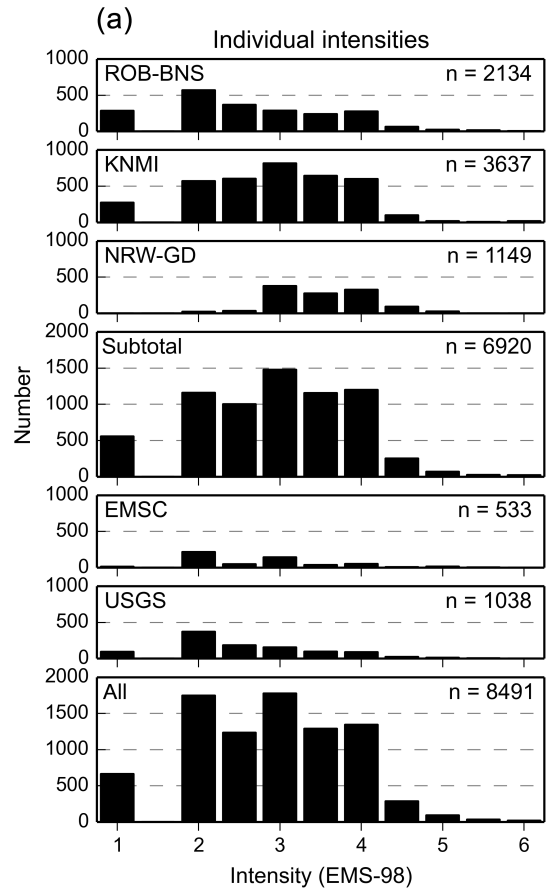

(b)

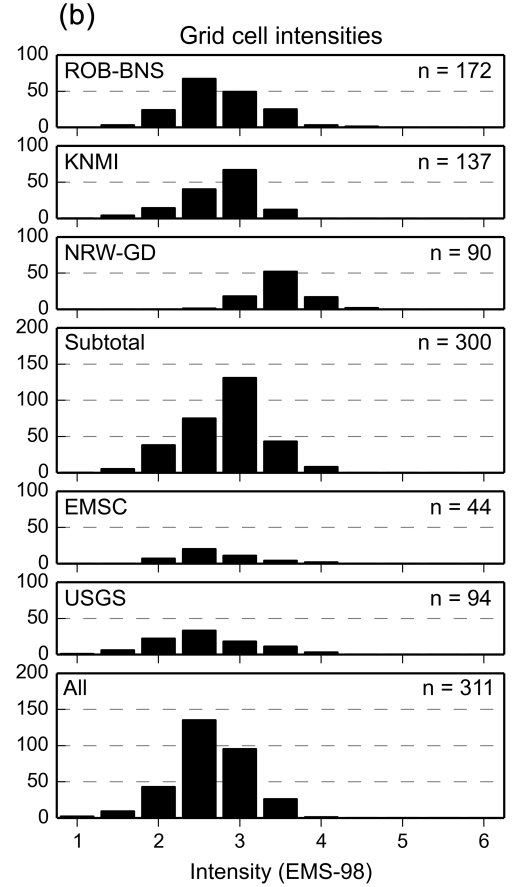

Figure 5. Goch earthquake intensity distributions binned per half-intensity units. Left: intensity distribution of the (geocoded, if possible) IDPs. NRW-GD lacks intensity I or "not-felt" entries. Right: grid cell intensity distributions of cells with at least three responses. The sum of responses submitted to the national institutes is far larger than the sum of those arriving at international agencies.

tensity correction could not be applied due to the absent floor question (Q8, Table S1). However, most people who reported to the USGS live in the Netherlands. Rescaling the KNMI data for floor level hardly affected grid cell intensity due to the low amount of reports from multistorey buildings. Therefore using USGS intensity data without applying floor-level correction is appropriate. Despite the low amount of grid cells on the USGS grid cell map (Fig. 4), USGS grid cell intensities are similar to the ROB-BNS intensities because the same intensity algorithm is used. USGS grid cells show an epicentral intensity of IV. The maximal CDI is 4.1 in the cell north of the epicentre.

\subsubsection{Comparing and merging databases}

With respect to the epicentre, the 2011 Goch earthquake was felt from Amsterdam (NL) in the northwest, Paderborn (DE) in the east, Darmstadt (DE) in the southeast to Brussels (BE) in the southwest. For the four countries involved, 10290 people responded to the online questionnaires of seven institutes (Table 1). The response submitted from furthest away came from Lille (FR) at $245 \mathrm{~km}$. After geocoding and by using the truncated location provided by the institutes, 8218 entries could be used for intensity analysis. Before merging macroseismic data of all institutes, first the quality of the different macroseismic sources is evaluated. The distribution histograms (Fig. 5) shows the individual and grid cell intensity distributions of all entries and for each institute sepa- rately, binned by half-intensity units. The number of cells in each histogram corresponds to the same amount of cells in Figs. 4 and 6. Cells with less than three responses are not included in the grid cell distribution. Several observations can be made when comparing the distribution of the individual entries with the grid cell histogram.

Although individual high-intensity IDPs exist, merging IDPs in grid cells and averaging their intensity reduces the influence of these overestimated intensities.

Intensity I has been systematically underreported. The macroseismic scale recommends taking into account not-felt percentages to assess an intensity degree. Unfortunately, the low not-felt percentages ( 2 to $11 \%$, Table 1 ) do not allow the assessment of this in a reliable intensity degree. Remember that none of the agencies has an observer's network to request not-felt data.

Merging intensities from national agencies results in a denser coverage of the area in which the earthquake occurred (Fig. 4). The sum of responses submitted to the national institutes is far larger than the sum of those arriving at international agencies. This illustrates the importance of the national web questionnaires, particularly for moderate magnitudes.

The mean intensity of the grid cell distribution of transfrontier inquiries (ROB-BNS, EMSC and USGS) is lower $(I=2.5)$ than the mean intensity of national inquiries $(I=3$ for KNMI and $I=3.5$ for NRW-GD). It seems plausible that the grid cell distribution of the NRW-GD database is higher 


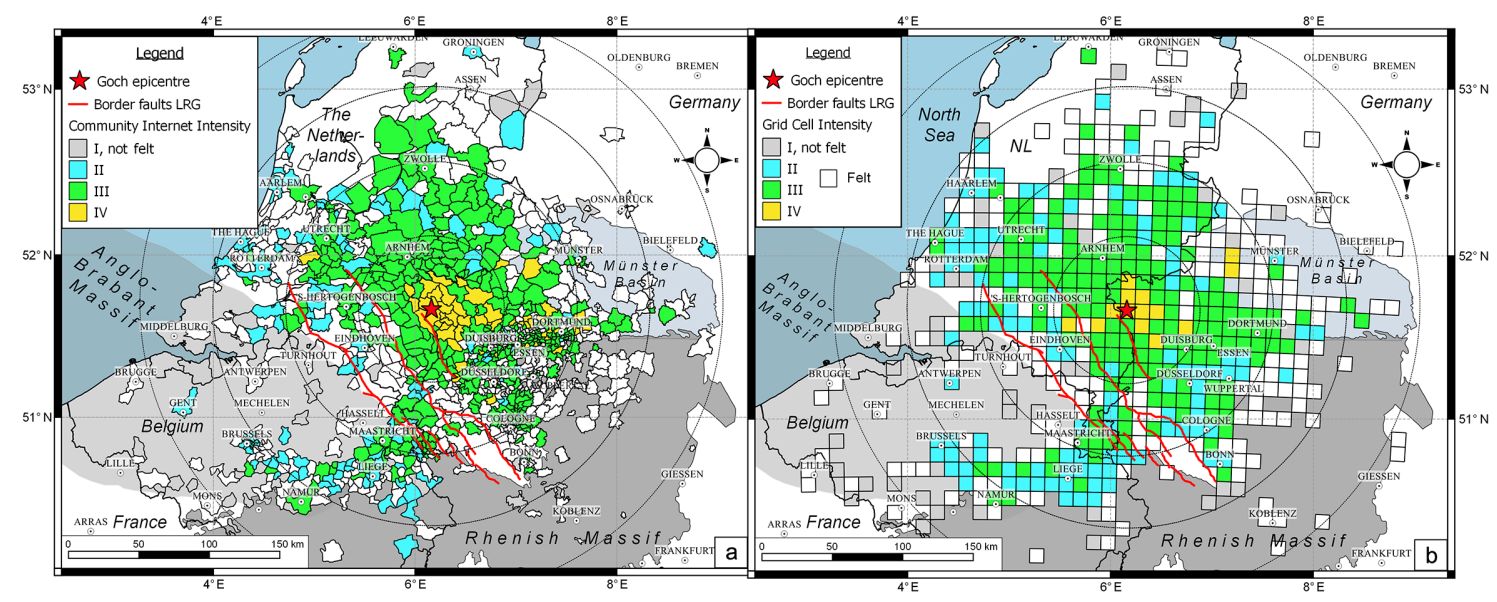

Figure 6. 2011 Goch earthquake intensity maps. (a) ZIP-CIIM using all 9087 entries (no NRW-GD). (b) Merged grid cell intensity map generated with only geocoded responses from ROB-BNS, KNMI, and intensity data from EMSC and USGS. Note the absence of macroseismic entries in northeast Belgium. Grid cell size is $100 \mathrm{~km}^{2}$. Circles represent 50,100, 150 and $200 \mathrm{~km}$ epicentral distance.

than KNMI because more responses are gathered from the epicentral area in Germany, whereas KNMI has no entries from this area.

The NRW-GD received many responses, some of which were located more than $150 \mathrm{~km}$ from the epicentre. Because intensity data could not be floor-level corrected, because notfelt responses are absent and because intensities of cities are mostly higher than in the database of other institutes, the NRW-GD intensity distribution is shifted towards higher intensities compared to other institutional distributions (Fig. 4). To avoid this systematic intensity overestimation, NRW-GD data were not further used when databases were merged for attenuation analysis but they are used to discuss the felt impact of the Goch earthquake.

After geocoding, floor-level correction and the exclusion of NRW-GD data, 7343 entries remained for final grid intensity analysis. In total, 663 people reported not to have felt the earthquake (intensity I; Table 1). An intensity could be assigned to 311 grid cells (Fig. 6b). Overall, 24 cells were not used as they contain only NRW-GD data and these are displayed as "felt" in the grid cell intensity map.

Intensity IV is distributed in a NW-SE direction, parallel to the main trend of the LRG and the Venlo Graben. Cells with intensity IV are all limited to the northeast of the epicentre, an area that corresponds to the horst structure of the Venlo Graben. The felt effect is distributed in a NW-NNE-SW pattern, but observations are lacking in the southwest part of the Netherlands and in northeast Belgium. The Goch earthquake was felt in central Belgium from Liège up to Brussels at larger epicentral distance than in northeast Belgium. Also, in the southwest extent of the LRG in Germany, i.e. the area west of Cologne and east of Aachen, the Goch event was mostly not perceived, resulting in an absence of grid cell intensities in that area. The Goch grid cell intensity distribution thus deviates from a full circular pattern as many observations are lacking in the cells in the southwest quadrant (Fig. 6).

\subsubsection{Attenuation analysis}

In Fig. 7a and $b$ the epicentral distance of each IDP and each centroid (geographical centre of the grid cell) is plotted versus the intensity of that observation and cell, respectively. To evaluate the mean distance decay and to derive an IAR through the decay, we use a moving bin technique in which the mean intensity is calculated for a bin width of $20 \mathrm{~km}$ which moves in overlapping steps of $2 \mathrm{~km}$. Using the mean value of moving bins has the advantage of deriving a smoother attenuation curve than using a stepping bin technique, in which the bin moves in steps similar to the bin width.

Several studies on historical macroseismology have provided regional attenuation intensity relations applicable to northwest Europe (e.g. Backun and Scotti, 2006; Hinzen and Oemisch, 2001; Stromeyer and Grünthal, 2009). IARs derived from historical data, however, always suggest a more widespread felt effect than spatially rich DYFI? data (Hough, 2013a, b). We therefore compare our derived IARs with the CEUS (Central and Eastern United States) attenuation prediction model of Atkinson and Wald (2007), applicable to intraplate earthquakes, because it is one of the only models that has been derived from online macroseismic data alone. In Fig. 7, CEUS-predicted intensities are illustrated for an $M_{\mathrm{w}} 3.7$ earthquake, i.e. the equivalent of an $M_{\mathrm{L}} 4.3$ event following the Reamer and Hinzen (2004) conversion for the LRG.

The mean Goch IAR is derived from both individual IDPs (Fig. 7a) and from grid cell intensity data (Fig. 7b). Although population density strongly biases the distribution of individual responses (significantly more responses in the first $40 \mathrm{~km}$; 

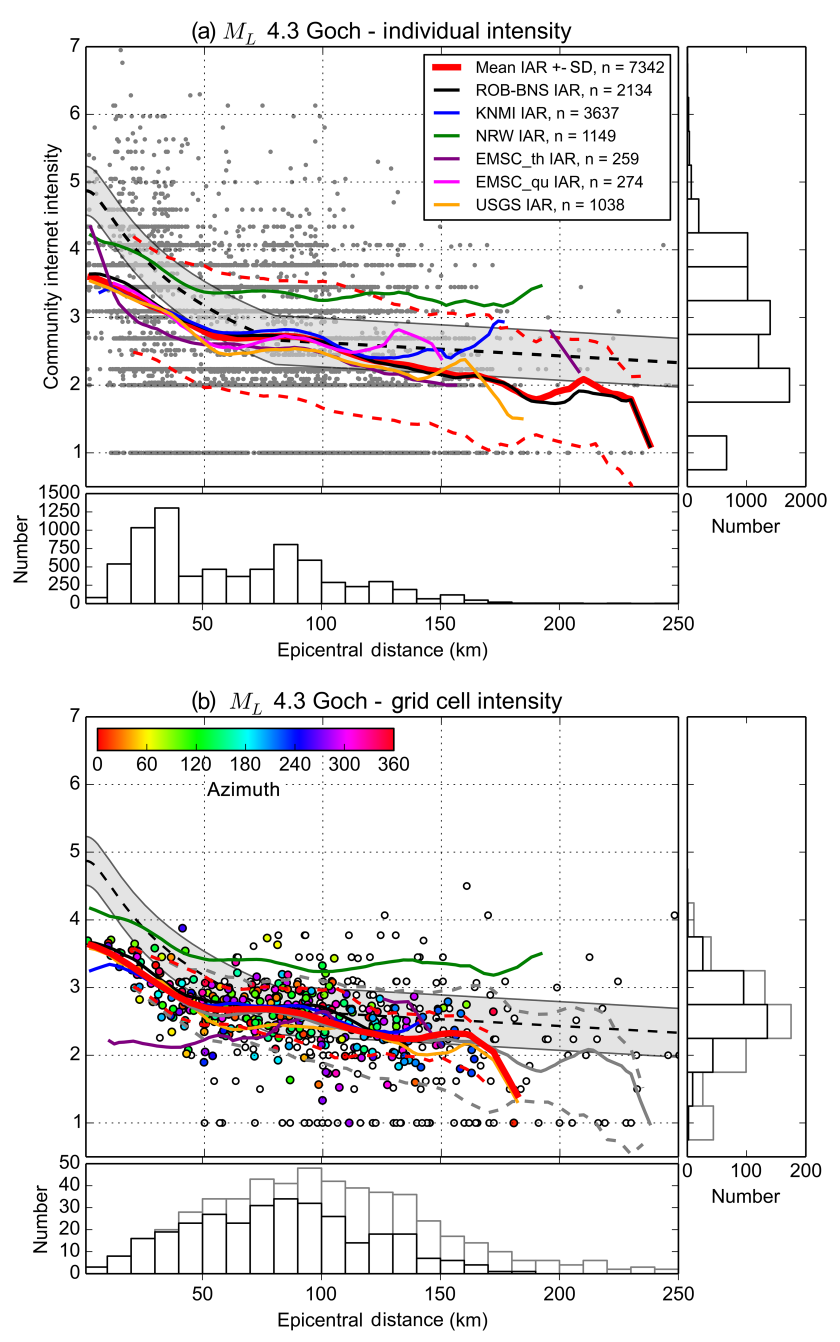

Figure 7. Intensity attenuation of the 2011 Goch earthquake. The horizontal and vertical histograms show the number of intensity distance points binned per $10 \mathrm{~km}$ and per half-intensity unit, respectively. Black line indicates CEUS-predicted intensities using Atkinson and Wald (2007) for an $M_{\mathrm{W}}$ 3.7. The intensity attenuation relations (IARs) are smoothed with a moving bin technique, with a bin window length of $20 \mathrm{~km}$ and overlapping steps of $2 \mathrm{~km}$. IARs in (a) are derived from individual agency data sources and from all merged individual IDPs (red line). (b) IARs are derived from grid cell centroid intensity data (red: cells > two responses; grey: all cells; other colours: see legend in (a)) after merging macroseismic datasets of all institutes (except NRW-GD). Colours represent the azimuthal position of the grid cell centre (centroid) relative to the seismic source. SD: standard deviation.

see horizontal histogram in Fig. 7a), the IAR is not affected by this as the shape of both mean curves is similar in the first $50 \mathrm{~km}$. The institutional IARs in Fig. 7a are calculated from the spatial data illustrated in Fig. 4. Institutional IARs derived through the grid cells confirm that the decay is similar, regardless of whether IARs are derived from individual or grid cell intensities.
The epicentral intensity $\left(I_{0}\right)$ of the 2011 Goch earthquake is unusually low. The epicentral centroid has a CDI of $I_{0}=3.7$, which is one intensity unit lower than the CEUSpredicted intensity. Apart from the NRW-GD and the EMSC (thumbnail) IARs, all institutional IARs show a similar $I_{0}$. In the first $50 \mathrm{~km}$, intensity decays with one intensity unit. Between 50 and $90 \mathrm{~km}$, the mean IAR flattens around intensity III. This amplifying effect is typically related to post-critical reflections from the Moho discontinuity that join direct seismic arrivals (Atkinson and Wald, 2007). The larger distance of the Moho bounce arrival in the CEUS prediction model $(80 \mathrm{~km})$ than in the Goch model $(65 \mathrm{~km})$ is probably related to the more shallow Moho in northwest Europe, especially below the LRG. The shapes of the ROB-BNS, KNMI, EMSC (questionnaire) and USGS IARs are all similar in the first $100 \mathrm{~km}$. Also the NRW-GD IAR (green line in Fig. 7) follows a similar shape, albeit at higher intensities. This observations suggests that although the questionnaires might differ (Table S1), the resulting intensity data are rather similar. Hence, performing an attenuation analysis by using grid cell information leads to an equal-area IAR that is not biased by the concentration of responses due to population density or the radial areal increment due to polar distribution.

A continuous intensity decay is observed between 100 and $140 \mathrm{~km}$ but at a slower rate than in the first $50 \mathrm{~km}$. This change in slope is related to the underreporting and lack of intensity I reports in the database in this distance range. The underreporting is visible in the histograms (Fig. 7b) where the frequency of centroids strongly decreases after $100 \mathrm{~km}$, although an increase should be expected because more people (and more grid cells) were affected by the earthquake at this distance range.

Overall, 111 responses were submitted from Brussels (population 1370000) at a distance of $165 \mathrm{~km}$. Despite this low population response percentage $(<5$ responses per 10000 inhabitants; Fig. 8b), it is still considerably larger than those from many other populated cities at closer epicentral distance where the Goch event was not perceived. In Belgium, no responses were submitted from the towns of Hasselt (91 km, population 56000$)$ or Mechelen $(135 \mathrm{~km}$, population $117000)$, and only two and three were submitted from Turnhout $(93 \mathrm{~km}$, population 50000$)$ and Antwerp $(125 \mathrm{~km}$, population 600000 ). In fact, all of Flanders (northern Belgium) hardly reported the earthquake, although it is a densely populated area (Fig. 8a).

Between 140 and $175 \mathrm{~km}$ epicentral distance, i.e. the furthest grid cells to which a reliable intensity could be assigned, a small intensity increase is indicated by the mean IAR through the grid cell data (Fig. 7b). This increase exemplifies an intensity amplification by the grid cells located between Liège (azimuth of $197^{\circ}$ ) and Brussels (azimuth of $237^{\circ}$ ). Remarkably, people from the towns of Assen $(150 \mathrm{~km}$, population 69000$)$ in the Netherlands and Osnabrück (145 km, population 196000), Bielefeld (168 km, population 327000$)$, Siegen $(153 \mathrm{~km}$, population 108000$)$ 


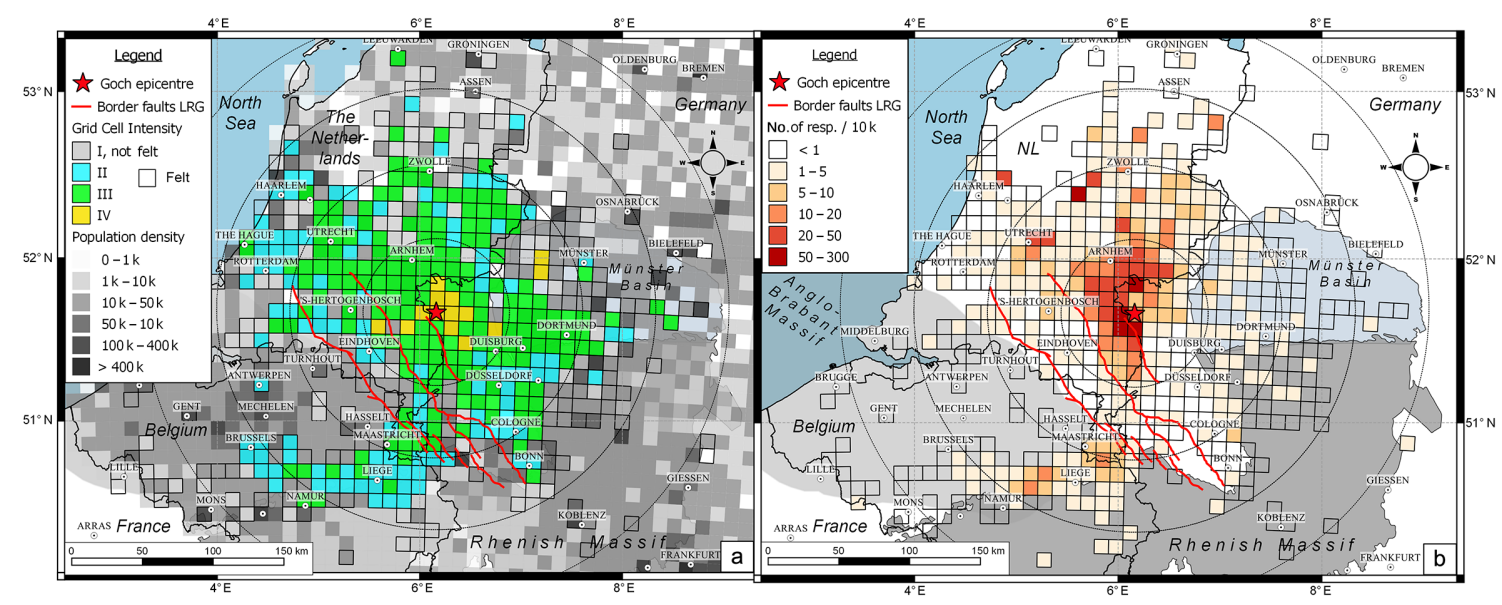

Figure 8. (a) Merged grid cell intensity map of the 2011 Goch earthquake overlaid on the population density grid cell map. Note the absence of macroseismic entries in the northern part of Belgium, despite its high population density. (b) Number of responses normalized for population density (no. of responses per 10000 people). On average the Goch event resulted in 9.8 responses per 10000 inhabitants, with 20 responses per 10000 in the epicentral cell and a maximum of 242 responses per 10000 in the cell $5 \mathrm{~km}$ south of the epicentre. Circles represent 50, 100, 150 and $200 \mathrm{~km}$ epicentral distance.

and Koblenz (175 km, population 110000) in Germany did not report having felt the earthquake, although they are at closer or similar distance than those living at Brussels. The lack of responses from these large cities shows that the amplifying shaking effect in the IAR between 140 and $170 \mathrm{~km}$ is caused by the Belgian macroseismic data and is clearly not a matter of population density.

\subsection{The 22 May 2015 Ramsgate earthquake (UK)}

Six institutes received macroseismic data for the Ramsgate earthquake: BGS, EMSC, USGS, BCSF and ROB-BNS. Although the Ramsgate earthquake occurred at 02:52:17 (local UK time), it was widely reported in the UK, France, Belgium and, to a lesser extent, in the Netherlands. The Ramsgate event $\left(M_{\mathrm{L}} 4.2\right)$ was perceived unusually far on the European continent, up to an epicentral distance of $360 \mathrm{~km}$. To analyse ground motion, all macroseismic data were requested from the above-mentioned institutes (Table 2). Only the IDPs from the BGS were not provided.

\subsubsection{BGS}

In total, 1860 felt reports were submitted to the BGS, most of them within a radius of $75 \mathrm{~km}$ from the epicentre (BGS, 2015a). People were awoken from their sleep because of a moderate shaking effect and, sometimes, a well-perceived sound. Most responses came from the towns of Ramsgate and Margate and from a few villages around these towns (BGS, 2015a). The event was also well perceived in Dover and Folkestone, respectively 2 and $31 \mathrm{~km} \mathrm{SW}$ of the epicentre, and in Hernebay $(23 \mathrm{~km} \mathrm{NW})$. The furthest location to which an intensity could be assigned was Norwich $(145 \mathrm{~km}$ $\mathrm{N}$, intensity II). The most distant reports have been received from near Hunstanton (195 km NW) and also some single reports from Leicester, Milton Keynes and Andover. Remarkably, although London $(\sim 100 \mathrm{~km}, \mathrm{~W})$ is at closer distance than Norwich, only a few responses were submitted from the capital. Apparently, big noisy cities do far worse in reporting earthquake perception than smaller towns. IDPs were not available from the BGS, but the map of felt locations was updated in real time on the BGS website (BGS, 2015b). The BGS groups IDPs from their online survey into $25 \mathrm{~km}^{2}$ cells using postcodes (and thus no geocoded addresses). Each grid cell is treated as a locality, reports are grouped accordingly and an intensity (EMS-98) is assigned to each locality from the aggregated data, provided that sat least five responses were submitted from in that cell (BGS, 2015a). For cells with less than five answers, the location is indicated as "felt" and no intensity is assigned. To 58 cells an intensity could be assigned (Fig. 9). The grid cell intensity distribution is dominated by intensities IV and V (Fig. 9) because of the majority of near-field reports. An intensity of $I_{0}=V$ was assigned to the epicentre area. This value, however, may be underestimated as, on Twitter, Mr. H. Smith reported cracks in his house and showed a few broken fallen roof tiles at Flete (Kent, $8 \mathrm{~km}$ from the epicentre; https://twitter.com/ Erb_Smith/status/601757488585830400). To explore potential damage degrees 1 or 2 in vulnerability classes A and B in the epicentral area, which are difficult to obtain from internet forms alone, a macroseismic field enquiry (cf. Sira, 2015) should be performed. The epicentral internet intensity of the French 2016 La Rochelle earthquake, for example, gave an $I_{0}=V$, whereas the post-seismic field survey resulted in maximum intensity VI (Sira et al., 2016). The cell at Flete on the Ramsgate intensity map may be tentatively in- 
creased up to intensity VI; however, this has to be confirmed in the field. No other damage has been reported elsewhere.

\subsubsection{BCSF}

The BSCF received 250 online individual witness reports and 135 official community reports after sending out a request through various online and official formularies in France. An intensity could be assigned to 83 of the 168 localities that responded. Between 45 and $80 \mathrm{~km}$ epicentral distance, the event was well perceived and a maximum intensity of IV could be assigned to 14 localities in the departments of Pasde-Calais and Nord (Sira and Schaming, 2015). These are all localities on the French North Sea coast. Intensity III could be observed in the towns of Calais and Boulogne-sur-Mer. Some rare and rather uncertain intensity III values from more than $100 \mathrm{~km}$ away probably result from the low amount of responses $(<3)$ within these localities. Following the EMS98 guidelines (i.e. the tremor is only felt at isolated places $(>1 \%)$ by individuals at rest and in a specially receptive position indoors), these higher intensities were rescaled to intensity II.

\subsubsection{ROB-BNS}

The ROB-BNS received 1980 individual responses from people living in Belgium, 6 entries from France, 6 from the Netherlands and 1 from the UK. Overall, $75 \%$ of the responses were submitted within $16 \mathrm{~h}$ after the earthquake. News flashes did not influence the response rate (Fig. S1). After removing false entries, geocoding and floor-level correction, 1617 intensities remained. Many reports were submitted from towns on the Belgian coast (between 85 and $120 \mathrm{~km}$ epicentral distance) and from the provinces of West Flanders, East Flanders and Hainaut. The Ramsgate grid cell intensity distribution shows a WNW-ESE orientation (Figs. 10 and S2). By contrast with the French coast, intensity IV was nowhere reached. Intensity III was assigned to the whole Belgian coast and to almost all of western Belgium, including cities of Bruges (III, $125 \mathrm{~km}$ ), Ghent (III, $160 \mathrm{~km}$ ) and Brussels (II-III, $210 \mathrm{~km}$ ). South of Brussels, intensity III was sometimes reached in isolated places. North of Brussels, intensity II alternates with areas with intensity I (not felt) and areas in which the earthquake was felt but to which no intensity could be assigned. Reports from large distances lead to intensity assessment of populated cities, such as Antwerp (II, $205 \mathrm{~km}$ ), Liège (II, $300 \mathrm{~km}$ ) and Verviers (II, $320 \mathrm{~km}$ ). Individual intensity I reports indicate that the event was not perceived in the northeast part of Belgium.

\subsubsection{EMSC}

1595 thumbnails and 368 questionnaires (divided into clusters; see Sect. 4.3.4) were submitted to the EMSC. A reliable intensity could be assigned to 39 clusters. The EMSC gathered a substantial amount of data, almost only from the
UK. Clusters are mostly located near the epicentre. In the near field, intensities VI and V are most frequent (Fig. 9). The thumbnail distribution is more scattered as more reports from a larger epicentral distance were submitted. This leads to mostly intensities III and IV. Only a minor amount of "notfelt" reports were submitted (Table 2). The Ramsgate event was perceived as far away as Grimsby and Stoke-on-Trent, respectively $270 \mathrm{~km} \mathrm{NNW}$ and $310 \mathrm{~km} \mathrm{NW}$ from the epicentre. However, these single reports probably come from people living on higher floors, which is not taking into account in EMSC attribution of the intensity value. Unfortunately this could not be checked in the data provided.

\subsubsection{USGS}

A limited amount of responses was submitted to the USGS after the Ramsgate earthquake. With 156 individual responses, an intensity could be assigned to 14 grid cells of $100 \mathrm{~km}^{2}$. A maximal intensity of IV was assigned to the epicentral area.

\subsubsection{Merging databases}

With respect to the epicentre, the 2015 Ramsgate earthquake was felt from Liège and Verviers (BE) in the east-southeast to Lille and Calais (FR) in the southeast, Norwich (UK) in the north, Stoke-on-Trent in the northeast, and Brighton in the southwest. For the four countries involved, 6222 people responded to the online questionnaires of five agencies to say they had felt the Ramsgate earthquake (Table 2). As with the Goch earthquake, the complex macroseismic situation in Europe is reflected in the fragmented datasets of the Ramsgate earthquake, but the responses submitted to national institutes (Fig. 9) cover the whole area in which the earthquake was felt. Numerical azimuthal analysis of the grid cell centroids relative to the epicentre (see Fig. S2) quantitatively proved that the Ramsgate intensity distribution is WNW-ESE-oriented with a mean circular azimuth of $112^{\circ}$ on the continent and $306^{\circ}$ in the UK.

To illustrate the shaking effect homogeneously, a $100 \mathrm{~km}^{2}$ grid cell intensity map was created after merging the clustered data of the EMSC, the $25 \mathrm{~km}^{2}$ grid cells of the BGS and from grid cell intensities calculated based on the USGS, BCSF and ROB-BNS IDPs (Fig. 10). Intensity VI was assigned to one cell. Intensity $\mathrm{V}$ was reached within $35 \mathrm{~km}$ of the epicentre. Intensity IV occurs in the whole of Kent, at isolated locations $75 \mathrm{~km}$ north of the epicentre and on the French coast. Intensity III occurs up to $150 \mathrm{~km}$ in the UK but up to $275 \mathrm{~km}$ on the continent. Intensity II was reported at some isolated locations in the UK, in the area north of Brussels in Belgium and around Arras in France. Intensity $\mathrm{I}$ is lacking almost everywhere except to a limited extent in the northeast of Belgium. 

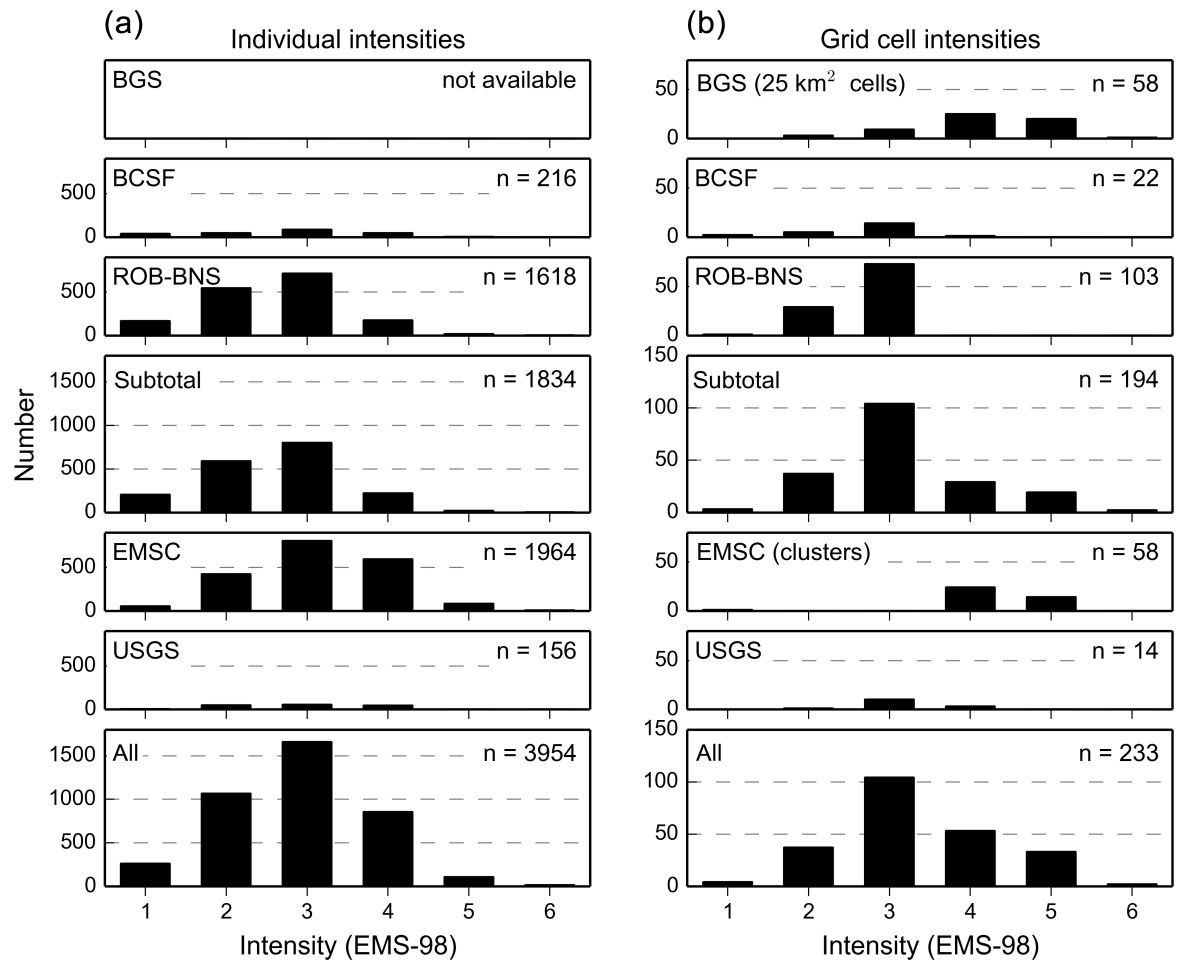

Figure 9. Ramsgate earthquake intensity distributions binned per full-intensity unit. Left: individual IDPs. Right: grid cell intensities of cells with more than two responses. BGS individual intensities were not available.

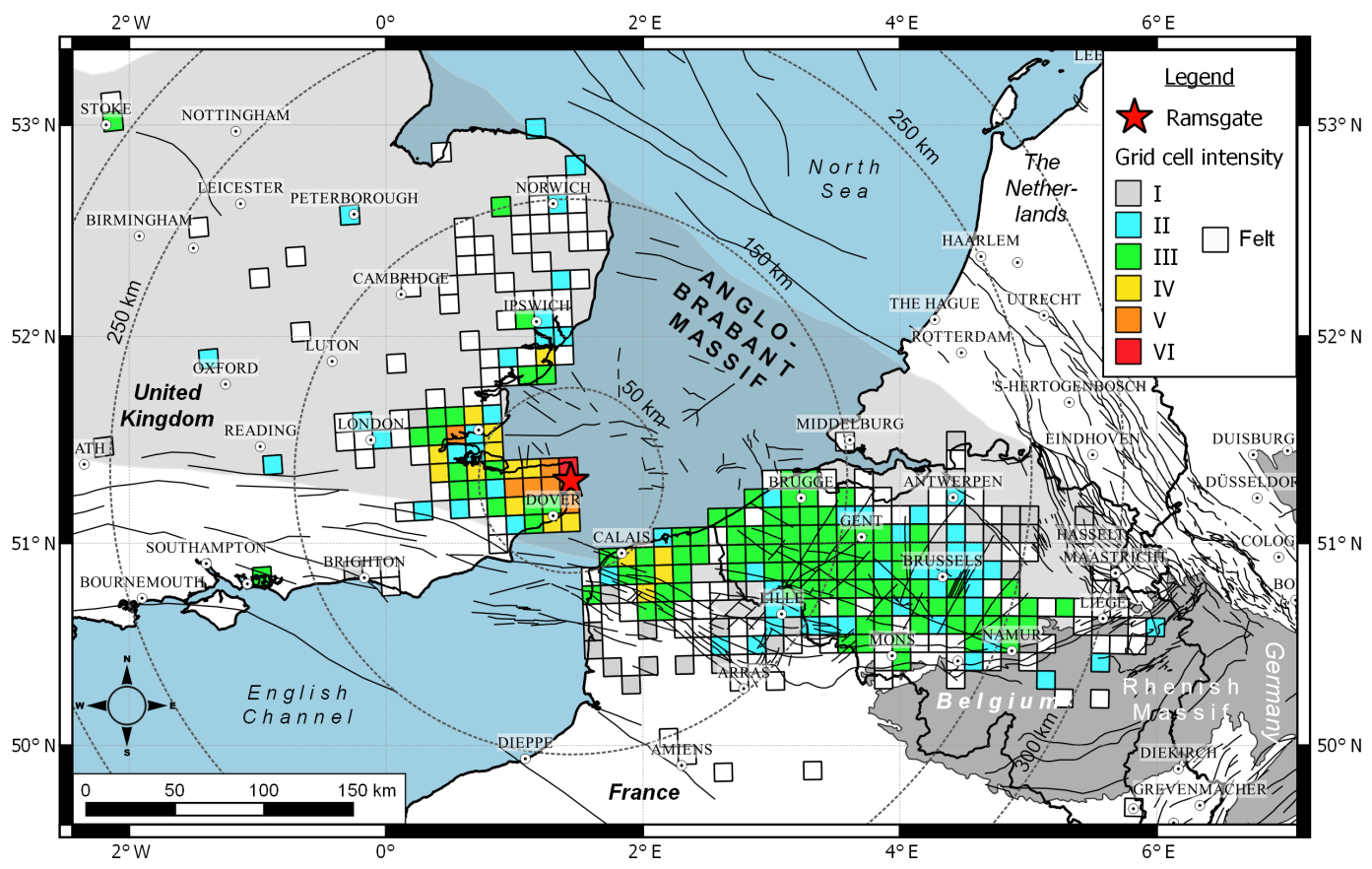

Figure 10. Grid cell intensity map of the 2015 Ramsgate earthquake. UK grid cells are merged from BGS, EMSC and USGS data. Cells on the continent result from merged macroseismic data from the ROB-BNS, EMSC and BCSF agencies. Note the particular WNW-ESE elongated distribution following the structure of the Anglo-Brabant Massif (indicated in grey). Grid cell size is $100 \mathrm{~km}{ }^{2}$. "Felt" cells contain less than three responses. 

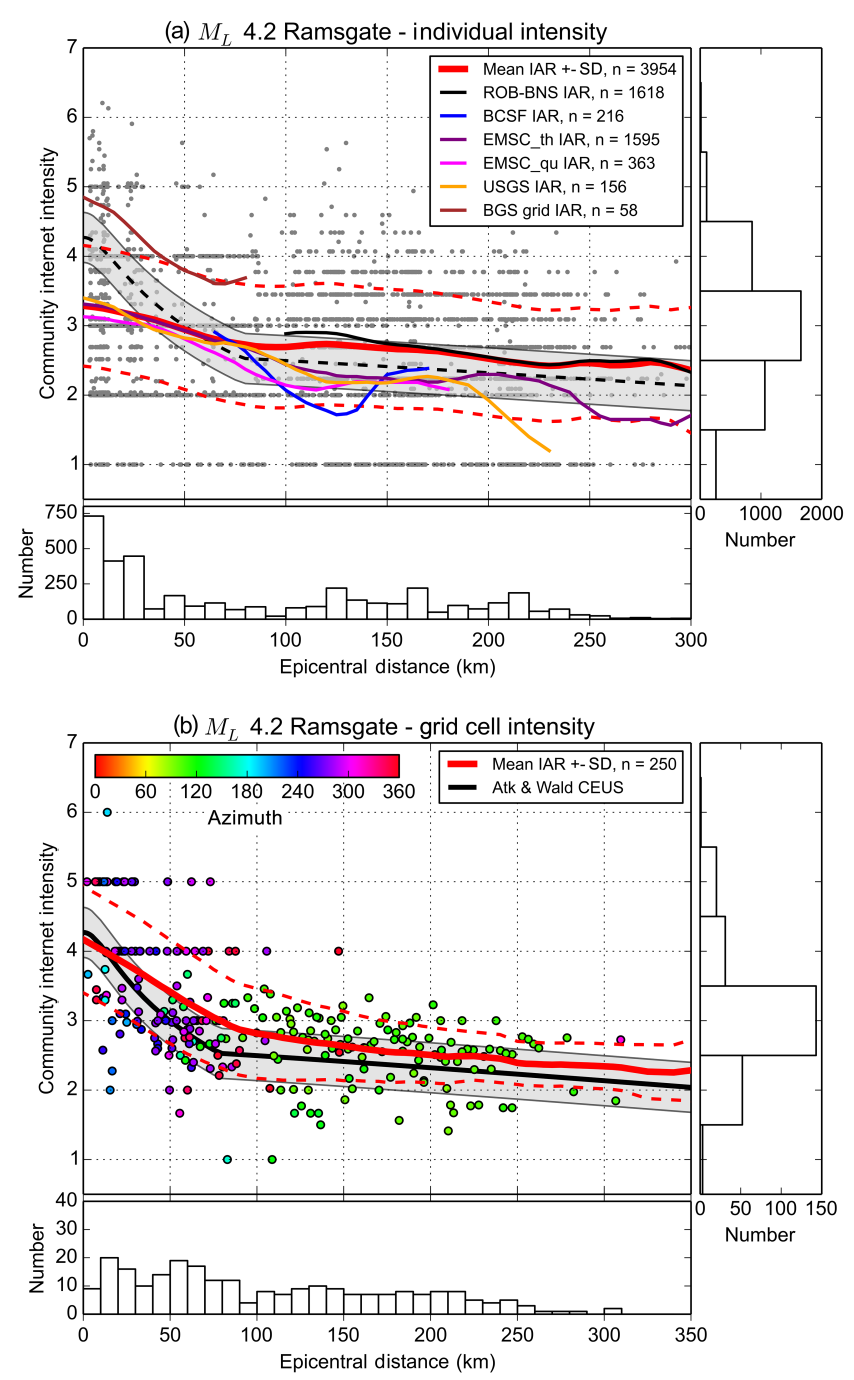

Figure 11. Intensity attenuation of the 2015 Ramsgate earthquake. (a) Institutional IARs (limited to areas with enough reports) and mean IAR (red) derived using individual intensity data from ROBBNS, USGS, EMSC and BCSF. (b) IAR derived from clusters (EMSC) and grid cell intensities. Colours represent the azimuthal position of grid cell centre (centroid) relative to the seismic source. The smoothed IARs are derived with a moving bin technique, with a bin window length of $20 \mathrm{~km}$ and moving steps of $5 \mathrm{~km}$. Horizontal and vertical histograms show the number of intensity distance points binned per $10 \mathrm{~km}$ and per intensity unit, respectively. Black line indicates CEUS-predicted intensities using Atkinson and Wald (2007) for an $M_{\mathrm{W}} 3.7$.

\subsubsection{Attenuation analysis}

The Goch intensity assessment showed that deriving an IAR through grid cell intensities leads to an equal-area IAR that is not biased by the concentration of individual responses due to population density. This result offers a great promise for sharing macroseismic data between seismological agencies that all have their own inquiry and their own way of clus- tering data because intensity cells can be exchanged without sharing any personal information. We test this method on the Ramsgate earthquake: an attenuation model is derived through the centroid data from the $25 \mathrm{~km}^{2}$ cells of the BGS, the clustered and thumbnail data of the EMSC and the $100 \mathrm{~km}^{2}$ intensity cells generated from ROB-BNS, USGS and BCSF IDPs. The Ramsgate IAR is compared to a CEUS prediction model for an $M_{\mathrm{w}} 3.7$ event (equivalent of an $M_{\mathrm{L}}$ 4.2 event) at $15 \mathrm{~km}$ depth.

A mean IAR was derived through the available IDPs and the grid cell intensities. In the distance histogram (Fig. 11a), a high number of cells is present in the epicentral area because different grid sizes are used. The epicentral intensity of the derived IAR $\left(I_{0}=4.5\right)$ is lower than the $I_{0}=V$ indicated by the BGS grid cells (and the $I=I V$ at Flete) because the IAR is calculated from the mean value of grid cell intensities in the first $20 \mathrm{~km}$. The USGS and EMSC (qu, th) institutional IARs (Fig. 11a) all fail to predict the proper epicentral intensity indicated in the BGS cells. Intensity attenuation occurs in the first $100 \mathrm{~km}$ at a lower rate than predicted by the CEUS model. This is probably related to the underreporting of low intensities in the first $100 \mathrm{~km}$ because the BGS felt intensities (white cells in Fig. 10), which probably correspond to II-III and contain intensity I, could not be included in the attenuation analysis. This drives IAR to intensity overestimation in the near field. A change in attenuation rate is present at $90 \mathrm{~km}$. Relating this bump to a Moho bounce effect remains subjective: Ramsgate was a coastal event and the IAR suffers from a lack of responses from (i) the North Sea area and also (ii) from the London area from where mostly only felt reports are available. Interestingly, the Ramsgate earthquake was felt further away and reported more on the continent than in the UK. Between 100 and $300 \mathrm{~km}$, the attenuation model is almost fully derived from intensities with an azimuth ranging between 90 and $120^{\circ}$ (Fig. 11). At these distances, the smoothed mean attenuation of the continent follows the CEUS model consistently.

\section{Discussion}

Depending on thickness and seismic impedance of surface sediments in a basin, surface ground motions can be strongly amplified and deamplified as well, resulting in large differences in site response. Prolonged scattering of long-period waves in a sedimentary basin is the critical factor for surface ground motion amplification. Intensity amplification in sedimentary basins, near field as well as at large epicentral distances, have been the subject of site response studies using solely macroseismic data (e.g. García Moreno and Camelbeeck, 2013; Haak et al., 1994; Martin et al., 2015; Sbarra et al., 2012a). The Goch and Ramsgate macroseismic data show significant deviations from the simple model of concentric isoseismals. The perception area of the Goch earthquake is stretched southwest but lacked any responses at closer dis- 


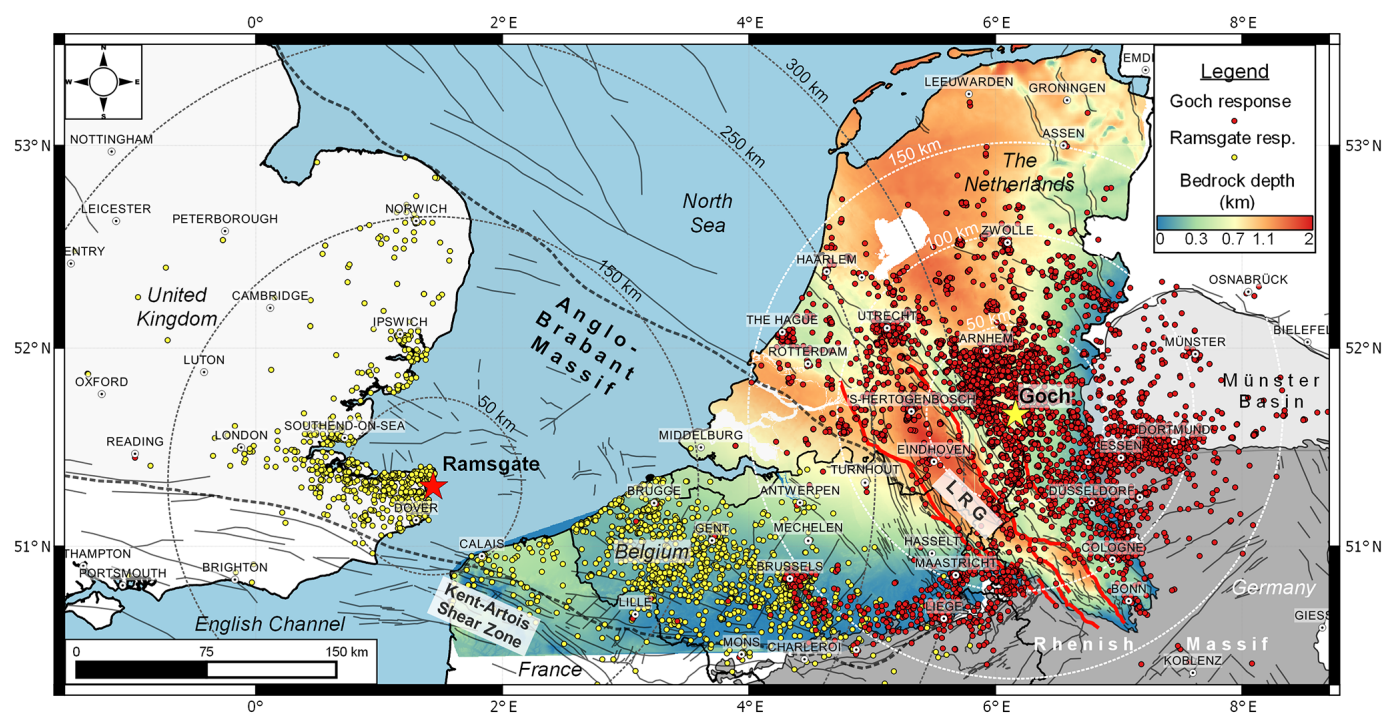

Figure 12. Combined felt distributions of the 2011 Goch earthquake (red) and 2015 Ramsgate earthquake (yellow) illustrated on a depth to bedrock map of northern Belgium, the Netherlands and western Germany. Note the absence of felt responses in northeast Belgium (between Antwerp and Hasselt), southwest of Eindhoven (NL) and southwest of Cologne due to the thick sedimentary cover. Map compiled from numerical data of the Databank Ondergrond Vlaanderen (2016; Belgian Data) and DINOloket (2016; Dutch data) combined with maps of Legrand (1968), Weber (2007), and Hager and Prüfert (1988). Bedrock depth in the UK is not shown.

tances in that direction (northeast Belgium). The Ramsgate event has a pronounced WNW-ESE distribution pattern and lacks any observations at large distances on the continent in azimuthal orientations other than 90 to $135^{\circ}$. The Goch nonconcentric shaking distribution is not a matter of population density as the affected area is densely populated (Fig. 8).

We computed the $P$ and $S$ wave far-field radiation pattern (Aki and Richards, 2002, Eq. 4.29) of the Goch strike-slip focal mechanism. The $P$ wave energy is largest in a southwest direction, while the $S$ wave energy is largest in the $\mathrm{S}$ and $\mathrm{E}$ directions. If $P$ waves were responsible for the felt reports, then a majority of people in northeast Belgium should have reported the earthquake as the whole area falls inside the highest-displacement lobe at the source. If $S$ waves are responsible for the felt perceptibility, which is mostly the case for the Goch earthquake ( $S$ waves have higher amplitudes than $P$ waves), only the Namur-Hasselt-Maastricht line falls in the lower radiated amplitudes. Although the $S$ wave radiation towards Antwerp is larger than towards Brussels, with the former at a closer distance than the latter, only 3 reports were submitted from Antwerp versus 83 from Brussels. Hence, the lack of responses in northeast Belgium cannot be linked to the source mechanism.

To explain the observed intensity patterns, we thus need to address the effect of regional geology, especially bedrock depth, on the seismic wave attenuation of frequencies to which humans are susceptible, both in the LRG and in and above the A-BM. Figure 12 shows the combined shaking effect of Ramsgate and Goch, illustrated on a map of the depth to seismogenic bedrock. The top of the seismogenic bedrock is interpreted as the surface with the highest acoustic impedance contrast between soft sediments and basement. In central and northern Belgium, the seismogenic bedrock either corresponds to the top of the A-BM or, when present, the top of the Cretaceous. The A-BM is present at the surface in incised river valleys in central Belgium and its top gradually deepens towards the Belgian-Dutch border where it is covered by $800 \mathrm{~m}$ of soft sediments (Legrand, 1968). In the Netherlands, the top of bedrock coincides with the base of the Lower North Sea Group (Van Adrichem Boogaert and Kouwe, 1993-1997) and reaches a maximum depth of $1500 \mathrm{~m}$ in the centre of the LRG below Eindhoven and 'sHertogenbosch (NL). In Germany, the seismogenic bedrock corresponds to the base of the Tertiary sediments in the LRG. Its deepest part $(>1300 \mathrm{~m})$ is located southwest of the ErftSwist Fault system in the southern part of the LRG.

\subsection{Ground motion (de-)amplification due to sediment thickness}

Figure 12 suggests that the felt area of the Ramsgate and Goch earthquakes, apart from geometrical amplitude attenuation, is controlled by the thickness of the sedimentary cover:

- Although Goch was reported from Cologne and Bonn (DE), no reports came in from southwest of the ErftSwist Fault system in the LRG, i.e. the deepest part of the LRG in Germany.

- In northeast Belgium macroseismic responses are absent both for Goch and Ramsgate. For Goch no responses are submitted from places at large bedrock 


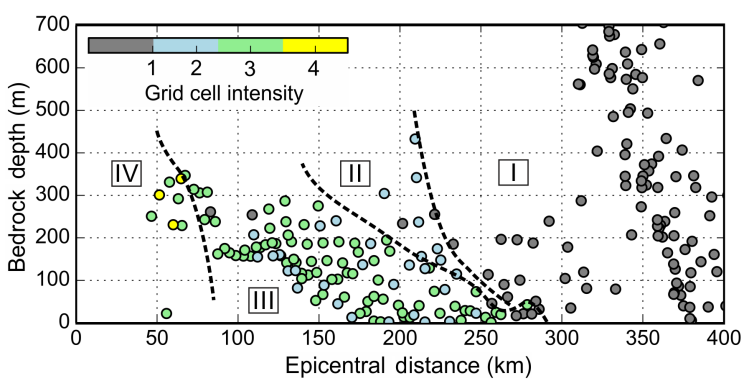

Figure 13. Bedrock depth of grid cell centroids (see Fig. 12) versus epicentral distance to the Ramsgate $M_{\mathrm{L}} 4.2$ earthquake. Only data from the continent. Dashed lines limit maximal depth-distance relation for the indicated intensities.

depth, but the event is reported between Liège and Brussels where bedrock is at a shallow depth $(\leq 100 \mathrm{~m})$.

- The integration of bedrock depth and the WNW-ESEoriented Ramsgate intensities on the continent shows that the farther from the source, the thinner the sedimentary cover above the A-BM must be in order to have perceived the event (Fig. 13). Regression analysis moreover indicates that the relation between distance and depth becomes steeper for lower intensities.

Based on these observations it can be concluded that at a close distance to the Goch earthquake source $(<60 \mathrm{~km})$, seismic energy was capable of penetrating the thick sedimentary cover in the LRG causing the earthquake to be felt at the surface. The Goch grid cell map shows intensity IV on the Venlo Horst (shallow bedrock), northeast of the Goch epicentre, but only intensity III in the Venlo Graben. This nearfield intensity difference exemplifies that attenuation in the Venlo Graben is related to the deeper bedrock (Fig. 12) and supports the conclusion that sediment thickness strongly influenced ground motion during the Goch earthquake.

For earthquakes of a similar magnitude, shallow events are more focused, have higher epicentral intensities and are felt far less further away than deeper events (Kövesligethy, 1907). Indeed, the $15 \mathrm{~km}$ deep Ramsgate earthquake was felt much further away $(\sim 360 \mathrm{~km})$ than the $10 \mathrm{~km}$ deep Goch event $(\sim 240 \mathrm{~km})$. In contrast, the epicentral intensity $\left(I_{0}=3.7\right)$ of the Goch earthquake is lower than any prediction model in the IAR and is considerably lower than the epicentral intensity $\left(I_{0}>5.0\right)$ of the Ramsgate earthquake. Such a low epicentral intensity of 3.7 would indicate a source $25 \mathrm{~km}$ deep, which contrasts with the instrumental $10 \mathrm{~km}$. Hence, the low epicentral intensity can only be explained by a local site effect, i.e. the sedimentary cover thickness ( $\sim 600 \mathrm{~m}$ at Goch; Fig. 12), attenuating higher frequencies at the epicentre. A similar attenuation effect in the LRG has been reported from the $17 \mathrm{~km}$ deep, $M_{\mathrm{L}} 5.81992$ Roermond (NL) earthquake (Camelbeeck and van Eck, 1994), where epicentral intensity was lower than predicted and did not ex- ceed VII on the MSK (Medvedev-Sponheuer-Karnik) scale (Haak et al., 1994; Meidow and Ahorner, 1994). This observation was explained due to the significant absorption of energy by $1500 \mathrm{~m}$ of sediments below Roermond (Ewald et al., 2006).

The observation that the Goch IAR is similar to the CEUS prediction in the first $50 \mathrm{~km}$ can be explained by a regional effect: a larger area is considered with increasing distance and intensity data are gathered above different geological units. This smooths the IAR in such way that it approaches the CEUS prediction.

At a larger distance, apart from energy decay, the thick sedimentary covers in northeast Belgium and in the LRG behave like a low-pass filter and attenuate seismic energy at higher frequencies, to which humans and 1-3 story buildings are susceptible. In central Belgium, the E-W elongated shape of the shaking felt was not due to a better transfer of seismic waves in the E-W direction but is related to an EW elongated zone where shallow bedrock depth $(\leq 100 \mathrm{~m})$ amplified seismic waves in the susceptible frequency range. This conclusion is corroborated by an intensity increase in the IAR (Fig. 7b) and indicates ground motion amplification at Brussels.

The NRW-GD received many reports from the Münster Basin (Fig. 12), i.e. the asymmetric synclinal basin the basement of which is made up of Palaeozoic and pre-Cretaceous Mesozoic rock and which is predominantly filled with soft marls up to $1400 \mathrm{~m}$. At its centre, the seismogenic bedrock is considered to be at $2000 \mathrm{~m}$ depth (Bilgili et al., 2009; Richwien et al., 1963). At Münster, the Goch earthquake resulted in a higher grid cell intensity (Fig. 7), which might be related to a basin effect. The large-distance responses reported from the southern border of the Münster Basin (up to $170 \mathrm{~km}$ ) can be related to basin-edge effects.

\section{2 $Q$ factor(s)}

Although it sounds counter-intuitive that a deep basement causes damping instead of long-period amplification, these M4 earthquakes have to be seen in the context of the depth and distance from the source. The attenuation by the sedimentary cover is valid for the considered moderatemagnitude earthquakes, but this will not hold for larger earthquakes that have a lower corner frequency. In the past, largermagnitude earthquakes have generated ground motions that were felt in the not-felt region of the Goch and Ramsgate earthquakes. The $2002 M_{\mathrm{L}} 4.9$ Alsdorf earthquake $\left(I_{0}=\mathrm{VI}\right.$; Hinzen, 2005), for instance, which occurred at the southwest border of the LRG, was widely perceived across the whole of northern Belgium, in the southern Netherlands and in western Germany. Also, the 1938 Zulzeke-Nukerke earthquake $\left(M_{\mathrm{S}} 5.0 ; I_{0}=\right.$ VII; see Fig. 3 for location) was felt in northeast Belgium at places with the largest bedrock depth. Damage reports of this event showed an E-W-oriented, elongated, non-circular distribution (Nguyen et al., 2004; Somville, 
1939; Camelbeeck et al., 2014). Also, the largest magnitude earthquake events in the $M_{\mathrm{L}}-0.7$ to $M_{\mathrm{L}} 3.2,2008-2010$ Walloon Brabant seismic swarm (Van Noten et al., 2015a, b) resulted in a predominant $\mathrm{E}-\mathrm{W}$ macroseismic distribution, illustrating the importance of the shallow Brabant Massif for the perception of these events.

The fact that Ramsgate was felt far away on the continent is, apart from its larger source depth, related to the shallow Brabant Massif and its thin sedimentary cover in central Belgium. The anisotropy in the felt distributions of the 2015 Ramsgate and the 1938 Zulzeke-Nukerke earthquakes results from a combination of different $Q$ factors: $Q$ is very high in the A-BM crust but low in the sedimentary cover. Hence, at places with a thin cover along-strike (WNW-ESE) of the A-BM, seismic waves are only attenuated by distance attenuation. Perpendicular to the A-BM tectonic axis, however, ground motions are attenuated (i) to the north by the increasing sedimentary cover (lower combined $Q$ factor) and (ii) to the south because seismic waves need to propagate through the WNW-ESE-oriented, crustal-rooted faults of the Kent-Artois Shear zone (Fig. 12), which has a lower $Q$ due to its fractured nature. This explains (i) why central Belgium is affected by a higher hazard than northern Belgium and (ii) why hardly any felt reports were submitted south of the Kent-Artois Shear zone in France. Compared to the widespread effect on the continent, the felt effect of the 2015 Ramsgate earthquake is rather limited in the UK as hardly any reactions were submitted from $>150 \mathrm{~km}$ distance. Following a similar reasoning as on the continent, this less widespread effect might be related to attenuating basin effects in the great London Basin and to intensity attenuation across the Kent-Artois Shear zone.

\section{Conclusions}

Transfrontier macroseismic maps are currently generated in real time in Europe by the EMSC and USGS. The current challenge in Europe, however, is to generate denser and more accurate shaking maps by merging all available intensity datasets from (inter)national agencies. It is necessary to collect the highest possible amount of datasets to ameliorate the uncertainty of the macroseismic intensity analysis. National agencies are best placed to do this as they still gather the highest number of responses (see subtotals in Figs. 5 and 9). The variety of questionnaires and the not always transparent intensity determination procedures of the different seismological agencies complicate this task. These differences highlight the importance of the European macroseismic scale for merging data. The results of this work strongly suggest that a common base in institutional web questionnaires needs to be established in order to generate transfrontier maps in which the full amount of transfrontier collected reports can be used. Only after a careful analysis of the different available ques- tionnaires and their impact on the intensity scale can we exchange and process intensity data in real time reliably.

For a reliable transfrontier intensity assessment, we advise starting with the inquiry of the institute that has the best spatial cover. Geocode if possible (if using Google, remember the 2500 addresses per day limit) and make sure a floor-level correction is applied; if not, add the question to your enquiry to avoid intensity overestimation. Create a network of volunteers that can be alerted in real time to increase responses and not-felt entries. This will allow the integration of the percentage of not-felt responses as the macroseismic scale recommends. Finally, collect and merge other institutional data to obtain the best coverage of the felt effect.

We demonstrated the functionality of geocoding and applying a grid cell method for merging (inter)national macroseismic databases. Although less data points are used, geocoding intensity locations minimizes the location uncertainties in a macroseismic map. A grid cell intensity map shows a more conclusive intensity distribution than a ZIP code intensity map. Grid cell maps are self-explanatory and avoid errors on the often subjective contouring for isoseismals. Gridding allows merging multiple macroseismic datasets collected by different seismological institutes in which the individual locations are (made) imprecise. Sharing grid cell information between seismological institutes can be a solution for macroseismic data exchange of transfrontierfelt earthquakes because all statistical intensity information is stored in the grid cells and legal issues, such as breaching a person's privacy, are avoided.

Macroseismic grid cell intensity analysis of the $M_{\mathrm{L}} 4.3$ 2011 Goch and the $M_{\mathrm{L}} 4.22015$ Ramsgate earthquakes proved that the non-circular macroseismic distributions of both events are controlled by distance attenuation, by the $Q$ factor in the bedrock and in the overlying sedimentary column, and by bedrock depth. For both earthquakes, a regional amplification effect occurs in central Belgium at shallow sites, even at places with a considerable distance to the sources. In northeast Belgium and in the southwest Lower Rhine Graben, the absence of macroseismic responses is related to seismic energy absorption by the thick sedimentary cover. The Ramsgate earthquake was farther felt than the Goch earthquake, which was of a similar magnitude, because of its larger source depth but predominantly due to an efficient wave propagation and low attenuation along the WNWESE tectonic axis of the Anglo-Brabant Massif, enhanced by the focal mechanism generating a directivity effect. These results emphasize the importance of an ancient tectonic structure on anisotropic wave propagation: seismic waves are less attenuated within a seismotectonic unit but are more strongly attenuated along travel paths perpendicular to the structural axis of the basement massif, particularly when they propagate through adjacent rheologically different units that are separated by deep crustal-rooted faults or that are buried by a sedimentary cover. 
Data availability. Topography data in Fig. 3 are from the Shuttle Radar Topography Mission (SRTM) and are available from the US Geological Survey. Macroseismic data were requested from the corresponding seismological institutes (See Appendix A). Bedrock data in Fig. 12 are openly available from Databank Ondergrond Vlaanderen (https://dov.vlaanderen.be) and DINOloket (https://www.dinoloket.nl/). All other data and maps used in this paper came from published sources listed in the references. Shapefiles to regenerate Figs. 6 and 10 are available in the Supplement. 


\section{Appendix A}

Table A1. Overview of European seismological institutes that provide an online macroseismic inquiry to request responses regarding earthquakes that have been felt. Hyperlinks to the online questionnaires are provided in the URL column. QRT? (quasi real time?) asks whether the gathered data are mapped and illustrated online in QRT: y(es), n(o). Institutional abbreviations are used in the text. See Appendix B for language abbreviations (all: multilingual inquiry).

\begin{tabular}{|c|c|c|c|c|}
\hline Country & Institute & Lang & URL & QRT ? \\
\hline Andorra & Centre d'estudis de la neu/de la muntanya d'Andorra & cat & CENMA & $\mathrm{n}$ \\
\hline Austria & $\begin{array}{l}\text { Seismological Service Department of Geophysics, } \\
\text { Central Institute for Meteorology and Geodynamics }\end{array}$ & ger & ZAMG & $\mathrm{n}$ \\
\hline \multirow[t]{4}{*}{ Belgium and Germany } & Royal Observatory of Belgium and Erdbebenstation Bensberg & nld & ROB-BNS & $\mathrm{y}$ \\
\hline & & fra & ROB-BNS & $\mathrm{y}$ \\
\hline & & ger & ROB-BNS & $\mathrm{y}$ \\
\hline & & eng & ROB-BNS & $\mathrm{y}$ \\
\hline Bulgaria & National Institute in Geophysics, Geodesy and Geography & bul & NIGG & $\mathrm{n}$ \\
\hline Denmark & Geological Survey of Denmark and Greenland & dan & GEUS & $\mathrm{n}$ \\
\hline \multirow[t]{2}{*}{ Finland } & University of Helsinki & fin & UH & $\mathrm{n}$ \\
\hline & & swe & UH & $\mathrm{n}$ \\
\hline France & French Central Seismological Office & fra & BCSF & $\mathrm{y}$ \\
\hline \multirow[t]{7}{*}{ Germany } & Universität Jena & ger & FSU & $\mathrm{n}$ \\
\hline & Ludwig-Maximilians-Universität München & ger & LMU & $\mathrm{n}$ \\
\hline & Hessisches Landesamt für Umwelt und Geologie (Hessen) & ger & HLNUG & $\mathrm{n}$ \\
\hline & Bundesanstalt für Geowissenschaften und Rohstoffe (Hanover) & ger & BGR & $\mathrm{n}$ \\
\hline & Landeserdbebendienst (Freiburg) & ger & LGRB & $\mathrm{n}$ \\
\hline & Geologischer Dienst Nordrhein-Westfalen (Krefeld) & ger & NRW-GD & $\mathrm{n}$ \\
\hline & Landesamt für Geologie und Bergbau (Rheinland-Pfalz - Saarland) & ger & LGB & $\mathrm{n}$ \\
\hline Hungary & Hungary Earthquake Information System & hun & HUN-Reng & $\mathrm{n}$ \\
\hline Iceland & Icelandic Met Office & isl & IMO & $\mathrm{n}$ \\
\hline Ireland & Dublin Institute for Advanced Studies & eng & DIAS & $\mathrm{n}$ \\
\hline Italy & Istituto Nazionale di Geofisica e Vulcanologia & ita & INGV & $\mathrm{y}$ \\
\hline Malta & Seismic Monitoring \& Research Unit, University of Malta & eng & SMRU & $\mathrm{y}$ \\
\hline Netherlands & Koninklijk Nederlands Meteorologisch Instituut & nld & KNMI & $\mathrm{n}$ \\
\hline Norway & Norwegian National Seismic Network, University of Bergen & nor & NNSN & $\mathrm{n}$ \\
\hline Portugal & Instituto Português do mar e da atmosfera & por & IPMA & $\mathrm{n}$ \\
\hline Romania & National Institute for Earth Physics & ron & NIEP & $\mathrm{n}$ \\
\hline Slovakia & Earth Science Institute of the Slovakian Academy of Sciences & slk & SAS & $\mathrm{n}$ \\
\hline Slovenia & Slovenian Environment Agency & slv & ARSO & $\mathrm{n}$ \\
\hline \multirow[t]{5}{*}{ Spain } & Instituto Geográfica Nacional & $\begin{array}{l}\text { ara, baq, cat, } \\
\text { eng, fra, por }\end{array}$ & IGN & $\mathrm{y}$ \\
\hline & Cartographic Institute of Catalonia & spa & ICGC & $\mathrm{y}$ \\
\hline & & cat & ICGC & $\mathrm{y}$ \\
\hline & Granada University & spa & UGR & $\mathrm{n}$ \\
\hline & University of Alicante & spa & UA & $\mathrm{n}$ \\
\hline \multirow[t]{4}{*}{ Switzerland } & Swiss Seismological Service & ger & SED & $\mathrm{y}$ \\
\hline & & fra & SED & $\mathrm{y}$ \\
\hline & & eng & SED & $\mathrm{y}$ \\
\hline & & ita & SED & $\mathrm{y}$ \\
\hline Sweden & Svenska nationella seismiska nätet, Uppsala Universitet & swe & SNSN & $\mathrm{n}$ \\
\hline UK & British Geological Survey & eng & BGS & $\mathrm{y}$ \\
\hline Global & European-Mediterranean Seismological Centre & all & EMSC & $\mathrm{y}$ \\
\hline Global & United States Geological Survey & eng & USGS & $\mathrm{y}$ \\
\hline
\end{tabular}




\section{Appendix B}

Table B1. Abbreviated languages. The translations for the word "earthquake" are used to find internet inquiries online. Abbreviated languages follow the international three-letter alpha-3/ISO 639-2 code.

\begin{tabular}{lll}
\hline Language & ISO 639-2 & "Earthquake" \\
\hline Aranese & ara & térratrem \\
Basque & baq & lurrikararen \\
Bulgarian & bul & zemetresenie \\
Catalan & cat & terratrèmol \\
Danish & dan & jordskaelv \\
English & eng & earthquake \\
Finnish & fin & maanjäristys \\
French & fra & tremblement de terre \\
German & ger & Erdbeben \\
Hungarian & hun & földrengési \\
Icelandic & isl & jarðskjálfti \\
Italian & ita & terremoto \\
Maltese & mlt & terremot \\
Dutch & nld & aardbeving \\
Norwegian & nor & jordskjelv \\
Portugese & por & terramoto \\
Romanian & ron & simtit \\
Slovak & slk & zemetrasenie \\
Slovenian & slv & potres \\
Spanish & spa & terremoto \\
Swedish & swe & jordskalv \\
\hline
\end{tabular}




\section{The Supplement related to this article is available online at doi:10.5194/se-8-453-2017-supplement.}

Competing interests. The authors declare that they have no conflict of interest.

Acknowledgements. The authors sincerely thank the 16503 individuals that responded to both earthquakes via all the online platforms. We acknowledge the following people for providing information on the institutional macroseismic data: B. Dost and G.-J. van den Hazel (KNMI), K. Lehmann (NRW-GD), R. Bossu and G. Mazet-Roux (EMSC), D. Wald and V. Quitoriano (USGS), and B. Baptie and S. Sargeant (BGS). K. Van Gheluwe, R. Gold, D. Wald, A. Schlupp, J. Batllo Ortiz, A. Izquierdo and the Seismology.be team of the ROB are thanked for discussion and support. We would like to thank R. Bossu, V. De Rubeis and an anonymous reviewer for their detailed comments and constructive criticism, which improved the paper. Figures were created in QGIS (2016). K. Van Noten was supported by the Fonds de la Recherche Scientifique (FNRS - Belgium) under grant PDR T.0116.14 "Influence of site effects in central Belgium on earthquake strong ground motions" and received additional FWO funding under travel grant K1G6616N.

Edited by: M. Malinowski

Reviewed by: V. De Rubeis, R. Bossu, and one anonymous referee

\section{References}

Agius, M. R., D'Amico, S., and Galea, P.: The Easter Sunday 2011 Earthquake Swarm Offshore Malta: Analysis on Felt Reports, in: Earthquakes and Their Impact on Society, edited by: D'Amico, S., Springer International Publishing, Cham, 631-645, 2016.

Ahorner, L.: Untersuchungen zur quartären Bruchtektonik der Niederrheinischen Bucht, Eiszeitalter und Gegenwart, 13, 24$105,1962$.

Aki, K. and Richards, P. G.: Quantitative Seismology, 2nd Edn. University Science Books, 704 pp., 2002.

Amorèse, D., Bossu, R., and Mazet-Roux, G.: Automatic Clustering of Macroseismic Intensity Data Points from Internet Questionnaires: Efficiency of the Partitioning around Medoids (PAM), Seismol. Res. Lett., 86, 1171-1177, 2015.

Atkinson, G. M. and Wald, G. J.: "Did you feel it?" Intensity Data: A Surprisingly Good Measure of Earthquake Ground Motion, Seismol. Res. Lett. 78, 2007.

Backun, W. H. and Scotti, O.: Regional intensity attenuation models for France and the estimation of magnitude and location of historical earthquakes, Geophys. J. Int., 164, 596-610, 2006.

BGS: Intensities for the Ramsgate Earthquake of 22 May 2015, British Geological Survey, available at: http://www.earthquakes. bgs.ac.uk/earthquakes/recent_events/RamsgateIntensity.pdf (last access: 4 May 2016), 2015a.

BGS: Ramsgate 22 May 2015 felt locations, British Geologial Survey, available at: http://www.earthquakes.bgs.ac.uk/earthquakes/ recent_events/ramsgate_22_may_2015_felt_locations.jpg (last access: 4 May 2016), 2015b.
Bilgili, F., Götze, H.-J., Pašteka, R., Schmidt, S., and Hackney, R.: Intrusion versus inversion - a 3D density model of the southern rim of the Northwest German Basin, Int. J. Earth Sci., 98, 571583, 2009.

Boatwright, J. and Phillips, E.: Exploiting the demographics of "Did You Feel It?" responses to estimate the felt areas of moderate earthquakes, Seismol. Res. Lett., 88, doi:10.1785/0220160041, 2017.

Bossu, R., Mazet-Roux, G., Douet, V., Rives, S., Marin, S., and Aupetit, M.: Internet users as seismic sensors for improved earthquake response, EOS Trans. Am. Geophys. Union, 89, 225-226, doi:10.1029/2008EO250001, 2008.

Camelbeeck, T. and van Eck, T.: The Roer Valley Graben earthquake of 13 April 1992 and its seismotectonic setting, Terra Nova, 6, 291-300, 1994.

Camelbeeck, T., Vanneste, K., Alexandre, P., Verbeeck, K., Petermans, T., Rosset, P., Everaerts, M., Warnant, R., and Van Camp, M.: Relevance of active faulting and seismicity studies to assessments of long-term earthquake activity and maximum magnitude in intraplate northwest Europe, between the Lower Rhine Embayment and the North Sea, Geol. S. Am. S., 425, 193-224, 2007.

Camelbeeck, T., Alexandre, P., Sabbe, A., Knuts, E., Moreno, D. G., and Lecocq, T.: The impact of earthquake activity in Western Europe from the historical and architectural heritage records, in: Intraplate earthquakes, edited by: Talwani, P., Cambridge University Press, 198-230, 2014.

Cara, M., Brüstle, W., Gisler, M., Kästli, P., Sira, C., Weihermüller, C., and Lambert, J.: Transfrontier macroseismic observations of the $\mathrm{Ml}=5.4$ earthquake of February 22, 2003 at Rambervillers, France, J. Seismol., 9, 317-328, 2005.

Databank Ondergrond Vlaanderen: Depth to bedrock map, available at: https://dov.vlaanderen.be, last access: 1 August 2016.

Dengler, L. A. and Dewey, J. W.: An intensity survey of households affected by the Northridge, California, earthquake of 17 January, 1994, B. Seismol. Soc. Am., 88, 441-462, 1998.

De Rubeis, V., Sbarra, P., and Tosi, P.: Regional macroseismic field and intensity residuals of the August 24, 2016, Mw $=6.0$ central Italy earthquake, Ann. Geophys.-Italy, 59, 2016.

DINOloket: Ondergrondmodellen, available at: https: //www.dinoloket.nl/, last access: 12 August 2016.

Ewald, M., Igel, H., Hinzen, K.-G., and Scherbaum, F.: Basinrelated effects on ground motion for earthquake scenarios in the Lower Rhine Embayment, Geophys. J. Int. 166, 197-212, 2006.

García Moreno, D. and Camelbeeck, T.: Comparison of ground motions estimated from prediction equations and from observed damage during the $M=4.61983$ Liège earthquake (Belgium), Nat. Hazards Earth Syst. Sci., 13, 1983-1997, doi:10.5194/nhess-13-1983-2013, 2013.

Grünthal, G., Musson, R. M. W., Schwarz, J., and Stucchi, M.: European Macroseismic Scale 1998, Cahiers du Centre Européen de Géodynamique et de Séismologie, 15, Conseil de l'Europe, Luxembourg, 1998.

Haak, H. W., van Bodegraven, J. A., Sleeman, R., Verbeiren, R., Ahorner, L., Meidow, H., Grünthal, G., Hoangtrong, P., Musson, R. M. W., Henni, P., Schenkova, Z., and Zimova, R.: The macroseismic map of the 1992 Roermond earthquake, the Netherlands, Geol. Mijnbouw, 73, 265-270, 1994. 
Haase, J. and Park, C. H.: Mapping Amplification of Earthquake Ground Motion in Indiana, Eearthquake Engineering Research Institude: "Learning from Earthquakes" Program, Purdue University, 37 pp., 2006.

Hager, H. and Prüfert, J.: Tertiär - Geologie am Niederrhein, Geologisches Landesamt, Nordrhein-Westfalen, Krefeld, 32-40, 1988.

Hinzen, K.-G.: Stress field in the Northern Rhine area, Central Europe, from earthquake fault plane solutions, Tectonophysics, 377 , 325-356, 2003.

Hinzen, K.-G.: Ground motion parameters of the July 22, $2002 M_{\mathrm{L}}$ 4.9 Alsdorf (Germany) earthquake, Bollettino di Geofisica Teoretica ed Applicata, 46, 303-318, 2005.

Hinzen, K.-G.: Seismic Analysis of the Accidental WWII Bomb Explosion in Euskirchen, Germany, on 3 January 2014, Seismol. Res. Lett., 85, 825-835, 2014.

Hinzen, K.-G. and Oemisch, M.: Location and Magnitude from seismic intensity data of recent and historic earthquakes in the northern Rhine area, Central Europe, B. Seismol. Soc. Am., 91, 40-56, 2001.

Hinzen, K.-G. and Reamer, S. K.: Seismicity, seismotectonics, and seismic hazard in the Northern Rhine Area, in: Continental Intraplate Earthquakes: Science, Hazard, and Policy Issues, edited by: Stein, S. and Mazzotti, S., Special Paper, 425, 225-242, Geological Society of America, 2007.

Horton, J. W., Chapman, M. C., and Green, R. A.: The 2011 Mineral, Virginia, earthquake, and its significance for seismic hazards in eastern North America - Overview and synthesis, Geol. S. Am. S., 509, 1-25, 2015.

Hough, S. E.: Initial Assessment of the Intensity Distribution of the 2011 Mw 5.8 Mineral, Virginia, Earthquake, Seismol. Res. Lett., 83, 649-657, 2012.

Hough, S. E.: Earthquake intensity distributions: a new view, Bull. Earthquake Eng., 12, 135-155, 2013a.

Hough, S. E.: Spatial Variability of "Did You Feel It?" Intensity Data: Insights into Sampling Biases in Historical Earthquake Intensity Distributions, B. Seismol. Soc. Am., 103, 2767-2781, 2013 b.

Hough, S. E.: Shaking from Injection-Induced Earthquakes in the Central and Eastern United States, B. Seismol. Soc. Am., 104, 2619-2626, 2014.

Hough, S. E., Martin, S. S., Gahalaut, V., Joshi, A., Landes, M., and Bossu, R.: A comparison of observed and predicted ground motions from the 2015 MW7.8 Gorkha, Nepal, earthquake, Nat. Hazards, 84, 1661-1684, 2016.

Kövesligethy, R.: Seismischer Stärkegrad und Intensität der Beben, Gerlands Beitrage zur Geophysik VII, Leipzig, 1907.

Knuts, E., Camelbeeck, T., and Alexandre, P.: The 3 December 1828 moderate earthquake at the border between Belgium and Germany, J. Seismol., 20, 419-437, 2015.

Kronrod, T., Radulian, M., Panza, G., Popa, M., Paskaleva, I., Radovanovich, S., Gribovszki, K., Sandu, I., and Pekevski, L.: Integrated transnational macroseismic data set for the strongest earthquakes of Vrancea (Romania), Tectonophysics, 590, 1-23, 2013.

Lecocq, T., Rapagnani, G., Martin, H., De Vos, F., Hendrickx, M., Van Camp, M., Vanneste, K., and Camelbeeck, T.: B-FEARS: The Belgian Felt Earthquake Alert and Report System, Cahiers du Centre Européen de Géodynamique et de Séismologie, 2009.
Legrand, L.: Le Massif du Brabant, Mémoires pour servir à l'explication des cartes géologiques et minières de la Belgique, Service Géologique de Belgique, Bruxelles, 1968.

Lesueur, C., Cara, M., Scotti, O., Schlupp, A., and Sira, C.: Linking ground motion measurements and macroseismic observations in France: a case study based on accelerometric and macroseismic databases, J. Seismol., 17, 313-333, 2012.

Mak, S. and Schorlemmer, D.: What Makes People Respond to "Did You Feel It?’?, Seismol. Res. Lett., 87, 119-131, 2016.

Martin, S. S., Hough, S. E., and Hung, C.: Ground Motions from the $2015 \mathrm{Mw} 7.8$ Gorkha, Nepal, Earthquake Constrained by a Detailed Assessment of Macroseismic Data, Seismol. Res. Lett., 86, 1524-1532, 2015.

Meidow, H. and Ahorner, L.: Macroseismic effects in Germany of the 1992 Roermond earthquake and their interpretation, Geol. Mijnbouw, 73, 271-279, 1994.

Melville, C., Levret, A., Alexandre, P., Lambert, J., and Vogt, J.: Historical seismicity of the Strait of Dover-Pas de Calais, Terra Nova, 8, 626-647, 1996.

Musson, R. M. W.: A critical history of British earthquakes, Ann. Geophys., 47, 597-609, 2004.

Nguyen, F., Van Rompaey, G., Teerlynck, H., Van Camp, M., Jongmans, D., and Camelbeeck, T.: Use of microtremor measurement for assessing site effects in Northern Belgium - interpretation of the observed intensity during the MS =5.0 June 111938 earthquake, J. Seismol., 8, 41-56, 2004.

Ottemöller, L. and Sargeant, S.: Ground-Motion Difference between Two Moderate-Size Intraplate Earthquakes in the United Kingdom, B. Seismol. Soc. Am., 100, 1823-1829, 2010.

Ottemöller, L., Baptie, B., and Smith, N. J. P.: Source Parameters for the 28 April $2007 \mathrm{Mw}$ 4.0 Earthquake in Folkestone, United Kingdom, B. Seismol. Soc. Am., 99, 1853-1867, 2009.

QGIS, D. T.: QGIS Geographic Information System, Open Source Geospatial Foundation Project, available at: http://qgis.osgeo.org (last access: 18 November 2015), 2016.

Reamer, S. K. and Hinzen, K.-G.: An Earthquake Catalog for the Northern Rhine Area, Central Europe (1975-2002), Seismol. Res. Lett., 75, 713-725, 2004.

Richwien, J., Schuster, A., Teichmiiller, R., and Wolburg, J.: Uberblick Uber das Profil der Bohrung Münsterland 1, Forcschr. Geol. Rheinld. Westf., 11, 1963.

Rovida, A. and Locati, M.: Archive of Historical Earthquake Data for the European-Mediterranean Area, in: Perspectives on European Earthquake Engineering and Seismology, edited by: Ansal, A., Springer International Publishing, Cham, 2, 359-369, 2015.

Sargeant, S. L., Stafford, P. J., Lawley, R., Weatherill, G., Weston, A. J. S., Bommer, J. J., Burton, P. W., Free, M., Musson, R. M. W., Kuuyuor, T., and Rossetto, T.: Observations from the Folkestone, U.K., Earthquake of 28 April 2007, Seismol. Res. Lett., 79, 672-687, 2008.

Sbarra, P., Tosi, P., and De Rubeis, V.: Web-based macroseismic survey in Italy: method validation and results, Nat. Hazards, 54, 563-581, 2010.

Sbarra, P., De Rubeis, V., Luzio, E., Mancini, M., Moscatelli, M., Stigliano, F., Tosi, P., and Vallone, R.: Macroseismic effects highlight site response in Rome and its geological signature, Nat. Hazards, 62, 425-443, 2012a. 
Sbarra, P., Tosi, P., De Rubeis, V., and Rovelli, A.: Influence of Observation Floor and Building Height on Macroseismic Intensity, Seismol. Res. Lett., 83, 261-266, 2012b.

Sira, C.: Macroseismic Intervention Group: The necessary field observation, Perspectives on European Earthquake Engineering and Seismology, 2, Springer, 455, 395-408, 2015.

Sira, C. and Schaming, M.: Séisme de Ramsgate du 22 mai 2015, rapport sismologique du BCSF, BCSF2016-R1, 25 pp., 2015.

Sira, C., Schlupp, A., and Schaming, M.: Séisme de La Rochelle du 28 avril 2016, Rapport du BCSF, BCSF2016-R1, 82 pp., 2016.

Somville, O.: Le tremblement de terre belge du 11 juin 1938, Publication de l'Observatoire Royal de Belgique, Imprimerie Duculot, Gembloux, 16 pp., 1939.

Souriau, A.: Quantifying felt events: A joint analysis of intensities, accelerations and dominant frequencies, J. Seismol., 10, 23-38, 2006.

Stefano, P. and Chiara, R.: A Macroseismic Method for Vulnerability Assessment of Rationalist Architectural Heritage, Procedia Economics and Finance, 18, 173-180, 2014.

Stromeyer, D. and Grünthal, G.: Attenuation relationship of macroseismic intensities in Central Europe, B. Seismol. Soc. Am., 99, 554-565, 2009.

Tosi, P., De Rubeis, V., Tertulliani, A., and Gasparini, C.: Spatial patterns of earthquake sounds and seismic source geometry, Geophys. Res. Lett., 27, 2749-2752, 2000.

Van Adrichem Boogaert, H. A. and Kouwe, W. F. P.: Lower North Sea Group, Stratigraphic Nomenclature of the Netherlands, 1993-1997.
Van Noten, K., Lecocq, T., and Camelbeeck, T.: The seismic activity in the Walloon Brabant and its relationship with the local and regional geological structure, Final report of BELSPO contract MO/33/028, Royal Observatory of Belgium, 79 pp., 2015a.

Van Noten, K., Lecocq, T., Shah, A. K., and Camelbeeck, T.: Seismotectonic significance of the 2008-2010 Walloon Brabant seismic swarm in the Brabant Massif (Belgium), Tectonophysics, 656, 20-38, 2015b.

Vanneste, K., Camelbeeck, T., and Verbeeck, K.: A Model of Composite Seismic Sources for the Lower Rhine Graben, Northwest Europe, B. Seismol. Soc. Am., 103, 984-1007, 2013.

Wald, D. J., Quitoriano, V., Dengler, L. A., and Dewey, J. W.: Utilization of the internet for rapid community intensity maps, Seismol. Res. Lett., 70, 680-697, 1999.

Wald, D. J., Quitoriano, V., Worden, B., Hopper, M., and Dewey, J. W.: USGS "Did You Feel It?" Internet-based macroseismic intensity maps, Ann. Geophys., 54, doi:10.4401/ag-5354, 2011.

Weber, B.: Bodenverstärkung in der südlichen Niederrheinischen Bucht, University of Cologne, PhD thesis, 142 pp., 2007.

Worden, C. B., Wald, D. J., Lin, K., Cua, G., and Garcia, D.: A revised ground-motion and intensity interpolation scheme for ShakeMap, B. Seismol. Soc. Am., 100, 3083-3096, 2000. 